\title{
Have primary emission reduction measures reduced ozone across Europe? An analysis of European rural background ozone trends 1996-2005
}

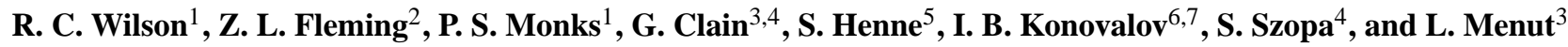 \\ ${ }^{1}$ Department of Chemistry, University of Leicester, University Road, Leicester, UK \\ ${ }^{2}$ National Centre for Atmospheric Science, Department of Chemistry, University of Leicester, University Road, Leicester, UK \\ ${ }^{3}$ Laboratoire de Météorologie Dynamique, École Polytechnique, 91128 Palaiseau, France \\ ${ }^{4}$ Laboratoire de Sciences du Climat et de l'Environnement, Gif-sur-Yvette, 91191 France \\ ${ }^{5}$ Empa, Swiss Federal Laboratories for Materials Testing and Research, Dübendorf, Switzerland \\ ${ }^{6}$ Institute of Applied Physics, Russian Academy of Sciences, Nizhniy Novgorod, Russia \\ ${ }^{7}$ Laboratoire Inter-Universitaire de Systèmes Atmosphériques, CNRS, Université Paris-Est and Université Paris 7, \\ Créteil, France
}

Correspondence to: P. Monks (p.s.monks@le.ac.uk)

Received: 12 May 2011 - Published in Atmos. Chem. Phys. Discuss.: 29 June 2011

Revised: 28 December 2011 - Accepted: 2 January 2012 - Published: 9 January 2012

\begin{abstract}
National and European legislation over the past $20 \mathrm{yr}$, and the modernisation or removal of industrial sources, have significantly reduced European ozone precursor emissions. This study quantifies observed and modelled European ozone annual and seasonal linear trends from 158 harmonised rural background monitoring stations over a constant time period of a decade (1996-2005). Mean ozone concentrations are investigated, in addition to the ozone 5th percentiles as a measure of the baseline or background conditions, and the 95th percentiles that are representative of the peak concentration levels. This study aims to characterise and quantify surface European ozone concentrations and trends and assess the impact of the changing anthropogenic emission tracers on the observed and modelled trends.
\end{abstract}

Significant $(p<0.1)$ positive annual trends in ozone mean, 5th and 95th percentiles are observed at 54\%, 52\% and $45 \%$ of sites respectively ( 85 sites, 82 sites and 71 sites). Spatially, sites in central and north-western Europe tend to display positive annual ozone trends in mean, 5th and 95th percentiles. Significant negative annual trends in ozone mean 5th and 95th percentiles are observed at $11 \%, 12 \%$ and $12 \%$ of sites respectively (18 sites, 19 sites and 19 sites) which tend to be located in the eastern and southwestern extremities of Europe. European-averaged annual trends have been calculated from the 158 sites in this study. Overall there is a net positive annual trend in ob-

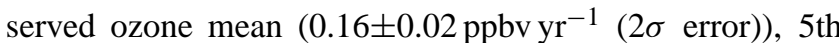
$\left(0.13 \pm 0.02 \mathrm{ppbv} \mathrm{yr}^{-1}\right)$ and 95 th $\left(0.16 \pm 0.03 \mathrm{ppbv} \mathrm{yr}^{-1}\right)$ percentiles, representative of positive trends in mean, baseline and peak ozone. Assessing the sensitivity of the derived overall trends to the constituent years shows that the European heatwave year of 2003 has significant positive influence and 1998 the converse effect; demonstrating the masking effect of inter-annual variability on decadal based ozone trends.

The European scale 3-D CTM CHIMERE was used to simulate hourly $\mathrm{O}_{3}$ concentrations for the period 1996-2005. Comparisons between the 158 observed ozone trends to those equivalent sites extracted from regional simulations by CHIMERE better match the observed increasing annual ozone (predominantly in central and north-western Europe) for 5 th percentiles, than for mean or 95th ozone percentiles. The European-averaged annual ozone trend in CHIMERE 5th percentiles $\left(0.13 \pm 0.01 \mathrm{ppbv} \mathrm{yr}^{-1}\right)$ matches the corresponding observed trend extremely well, but displays a negative trend for the 95th percentile $\left(-0.03 \pm 0.02 \mathrm{ppbv} \mathrm{yr}^{-1}\right)$ where a positive ozone trend is observed. Inspection of the EU-averaged monthly means of ozone shows that the CHIMERE model is overestimating the summer month $\mathrm{O}_{3}$ levels.

In comparison to trends in EMEP emissions inventories, with the exception of Austria-Hungary, we do not find that anthropogenic $\mathrm{NO}_{\mathrm{x}}$ and $\mathrm{VOC}$ reductions have a substantial 
effect on observed annual mean $\mathrm{O}_{3}$ trends in the rest of Europe. On a ten year time-scale presented in this study, $\mathrm{O}_{3}$ trends related to anthropogenic $\mathrm{NO}_{\mathrm{x}}$ and $\mathrm{VOC}$ reductions are being masked as a result of a number of factors including meteorological variability, changes in background ozone and shifts in source patterns.

\section{Introduction}

Ozone is central to the chemistry of the troposphere owing to its role in the initiation of photochemical oxidation processes via photolysis and subsequent reactions of the photoproducts to form the hydroxyl radical (Monks, 2005). Tropospheric ozone is also recognised to be a threat to human health (WHO, 2003), have a deleterious impact on vegetation (Fowler et al., 1999, 2009) as well as being an important tropospheric greenhouse gas (IPCC, 2007). Tropospheric ozone is a secondary pollutant formed from the chemistry of the nitrogen oxides and volatile organic compounds (VOCs) (Monks, 2005).

Throughout the whole troposphere the concentrations of ozone have changed in the modern era characterised by the enhanced emissions of precursors from industrialisation. Analysis of historical ozone records indicate that tropospheric ozone levels in both hemispheres have increased by a factor of 3 to 4 over the recent centuries (Anfossi et al., 1991; Pavelin et al., 1999; Sandroni et al., 1992; Staehelin et al., 1994; Volz and Kley, 1988).

The tropospheric ozone budget at any given place is a complex combination of photochemical processes and physical processes, i.e. photochemical production or destruction of ozone, stratospheric-tropospheric exchange (STE) and destruction of ozone at the Earth's surface.

Quantitative establishment of temporal ozone trends is important for quantifying the impact of changing precursor emissions and also from the perspective of local and regional air quality control in terms of import/export of ozone and the amount that is locally or regionally controllable. Observed ozone trends are a challenge to interpret as there are a number of possible factors responsible (Cape, 2008) such as (a) changes in anthropogenic emissions of precursors (both regional and global), (b) effects of variable precursor emissions from biomass burning (both regional and global), (c) changes in stratosphere-troposphere exchange trends, (d) changes in geographical emission patterns and (e) changes in air-mass transport patterns. Long-term series of high quality data are required in order to detect the trend amongst the large inter annual variation. Jonson et al. (2006) have discussed many of these effects in relation to ozone trends.

There has been substantial focus to date on quantifying hemispheric "background" trends in ozone (The Royal Society, 2008). There are different definitions of background (Chan and Vet, 2010; Parrish et al., 2009; The Royal Soci- ety, 2008) but a pragmatic definition is that it is ozone measured at a site without the influence of strong local effects. This leads to a hierarchy of background measurements from hemispheric background, to regional, rural and urban. Much of the focus in hemispheric background trends has been on the detection and attribution of ozone trends in marine air entering the western seaboards of the USA/Canada and Europe (Carslaw, 2005; Chan and Vet, 2010; Cooper et al., 2010a; Derwent et al., 2007a; Jaffe and Ray, 2007; Law et al., 2010; Council, 2009; Oltmans et al., 2006; Parrish et al., 2009; Simmonds et al., 2004). Measurements of marine inflow can provide the opportunity to sample ozone in an environment without the confounding influence of continental emissions while at the same time having acted as an integrator of upwind continental-scale emissions. It is worth noting that marine in-flow measurements could be influenced by the effects of recirculation of downwind continental air over the oceans associated with synoptic-scale systems. There remains some discussion as to the attribution of the observed trends (Oltmans et al., 2006, 2008; Parrish et al., 2009; Cooper et al., 2010b).

A review of Northern Hemisphere ground-based "background" ozone trends (including several European sites) has shown a slowly increasing average ozone concentration in the Northern Hemisphere of $0.5-2 \% \mathrm{yr}^{-1}$ (variable uncertainties Vingarzan (2004) and references therein). Long-term European background ozone trends of $1.5 \pm 0.9 \% \mathrm{yr}^{-1}$ at Hohenpeissenberg (1971-1983) (Logan, 1985), $1.48 \pm 0.51 \% \mathrm{yr}^{-1}$ at Zugspitze (1978-1995) (Oltmans et al., 1998), $0.31 \pm 0.12 \mathrm{ppbv} \mathrm{yr}^{-1}$ at Mace Head (1987-2007) (Derwent et al., 2007b) have been observed, with more recent annual ozone trends at background European sites summarised by country in Table 1 . Many previous studies investigate $\mathrm{O}_{3}$ trends at a single or small number of sites. Where available, the annual trends ( $\mathrm{ppbv} \mathrm{yr}^{-1}$ or $\% \mathrm{yr}^{-1}$ ) of individual sites has been averaged from literature values with statistical significance $(p<0.1)$ to ascertain an average trend by country. Values reported from this study in Table 1 are the average of annual trends ( $\mathrm{ppbv} \mathrm{yr}^{-1}$ and $\% \mathrm{yr}^{-1}$ ) calculated for individual sites within each country with statistically significant trends $(p<0.1)$. The period of trend analysis varies in each case study, rendering it difficult to compare all sites in a uniform manner. Despite the increasing ozone trends in the northern hemisphere, the upward trends appear to be continuing at a reduced rate since the 1980s (Guicherit and Roemer, 2000).

In many respects continental/regional trends are more difficult to characterise owing to a greater number of competing effects. Jenkin (2008) concluded from an analysis of UK ozone data that the observations at a given location were influenced by a combination of global/hemispheric, regional- and local-scale effects with the net trend being dependent on the relative influence of these contributions which can vary spatially and temporally. For the UK, he noted three major influences (i) a gradual increase in 
Table 1. Mean trends by country from this study (bold) compared to literature values with $95 \%$ confidence limits given, standard error given in square brackets. $N=$ number of measurement sites used to calculate the average trend. Sig = significance of trend, where $\diamond$ statistically significant $(p<0.1), \oplus$ not statistically significant $(p>0.1)$ and - not stated.

\begin{tabular}{|c|c|c|c|c|c|c|c|}
\hline Country & Period & $N$ & Trend $\left(\% \mathrm{yr}^{-1}\right)$ & Sig. & $N$ & Trend (ppbv yr $\left.{ }^{-1}\right)$ & Sig. \\
\hline \multirow[t]{3}{*}{ Austria } & $1995-2004^{1}$ & & & & 1 & $0.12 \pm 0.34$ & $\diamond$ \\
\hline & $1994-2003^{1}$ & & & & 1 & $0.25 \pm 0.24$ & $\diamond$ \\
\hline & 1996-2005 & 32 & 1.76 & $\diamond$ & 32 & 0.41 & $\diamond$ \\
\hline Belgium & 1996-2005 & 7 & 0.23 & $\diamond$ & 8 & 0.14 & $\diamond$ \\
\hline Czech Republic & 1996-2005 & 6 & 0.61 & $\diamond$ & 6 & 0.15 & $\diamond$ \\
\hline Estonia & 1996-2005 & 1 & -1.15 & $\diamond$ & 1 & -0.38 & $\diamond$ \\
\hline \multirow{5}{*}{ France } & $1995-2003^{2}$ & 9 & $0.6 \pm 1.3$ & - & & & \\
\hline & $1997-2003^{2}$ & 1 & 2.00 & $\diamond$ & & & \\
\hline & $1995-2003^{2}$ & 7 & -0.48 & $\oplus$ & & & \\
\hline & $1997-2005^{3}$ & 1 & 1.6 & $\oplus$ & & & \\
\hline & 1996-2005 & 1 & 0.95 & $\diamond$ & 1 & 0.29 & $\diamond$ \\
\hline \multirow[t]{4}{*}{ Germany } & $1995-2004^{1}$ & & & & 1 & $0.03 \pm 0.39$ & $\diamond$ \\
\hline & $1994-2003^{1}$ & & & & 1 & $0.30 \pm 0.38$ & $\diamond$ \\
\hline & $1978-2004^{4}$ & 1 & $12.6[ \pm 0.8] \% /$ decade & - & & & \\
\hline & 1996-2005 & 24 & 1.27 & $\diamond$ & 21 & 0.25 & $\diamond$ \\
\hline \multirow[t]{3}{*}{ Great Britain } & $1990-2006^{5}$ & & & & 12 & 0.56 & - \\
\hline & $2000-2007^{6}$ & & & & 1 & $0.07[ \pm 0.15]$ & $\oplus$ \\
\hline & 1996-2005 & 9 & 1.48 & $\diamond$ & 9 & 0.3 & $\diamond$ \\
\hline \multirow{3}{*}{$\begin{array}{l}\text { Greece } \\
\text { Hungary }\end{array}$} & $1998-2002^{7}$ & & & & 1 & $-3.4 \pm[0.2]$ & $\diamond$ \\
\hline & $1990-2002^{8}$ & & & & 1 & 0.32 & - \\
\hline & 1996-2005 & 1 & -4.11 & $\diamond$ & 1 & -1.28 & $\diamond$ \\
\hline \multirow[t]{6}{*}{ Ireland } & $1995-2007^{6}$ & & & & 1 & $-0.12[ \pm 0.07]$ & $\diamond$ \\
\hline & $2001-2007^{6}$ & & & & 1 & $-0.05[ \pm 0.15]$ & $\oplus$ \\
\hline & $2000-2007^{6}$ & & & & 1 & $0.27[ \pm 0.10]$ & not stated \\
\hline & $1995-2007^{9}$ & & & & 1 & $0.31 \pm 0.31$ & $\diamond$ \\
\hline & $1990-2004^{10}$ & & & & 1 & $0.18 \pm 0.04$ & $\diamond$ \\
\hline & 1996-2005 & 1 & - & $\oplus$ & 1 & - & $\oplus$ \\
\hline Italy & 1996-2005 & 1 & 6.05 & $\diamond$ & 1 & 0.23 & $\diamond$ \\
\hline \multirow[t]{2}{*}{ Lithuania } & $1988-2000^{11}$ & & & & 1 & 0.56 & - \\
\hline & 1996-2005 & 1 & 1.14 & $\diamond$ & 1 & 0.31 & $\diamond$ \\
\hline Latvia & 1996-2005 & 1 & -1.92 & $\diamond$ & 1 & -0.33 & $\diamond$ \\
\hline The Netherlands & 1996-2005 & 7 & 1.79 & $\diamond$ & 8 & 0.26 & $\diamond$ \\
\hline Norway & 1996-2005 & 1 & -0.87 & $\diamond$ & 1 & -0.16 & $\diamond$ \\
\hline Poland & 1996-2005 & 1 & -1.38 & $\diamond$ & 1 & -0.43 & $\diamond$ \\
\hline Portugal & 1996-2005 & 1 & - & $\oplus$ & 1 & - & $\oplus$ \\
\hline Slovinia & 1996-2005 & 1 & -2.22 & $\diamond$ & 1 & -0.24 & $\diamond$ \\
\hline Spain & 1996-2005 & 5 & -1.83 & $\diamond$ & 5 & -0.54 & $\diamond$ \\
\hline \multirow[t]{4}{*}{ Switzerland } & 1995-2004 1 & & & & 1 & $0.34 \pm 0.38$ & $\diamond$ \\
\hline & $1994-2003^{1}$ & & & & 1 & $0.54 \pm 0.36$ & $\diamond$ \\
\hline & $1991-1999$ & & & & 4 & 0.58 & - \\
\hline & 1996-2005 & 5 & 1.76 & $\diamond$ & 5 & 0.21 & $\diamond$ \\
\hline
\end{tabular}

${ }^{1}$ Chevalier et al. (2007), ${ }^{2}$ Sicard et al. (2009), ${ }^{3}$ Sicard et al. (2010), ${ }^{4}$ Oltmans et al. (2006), ${ }^{5}$ Jenkin (2008), ${ }^{6}$ Tripathi et al. (2010), ${ }^{7}$ Gerasopoulos et al. (2005), ${ }^{8}$ Haszpra et al. (2003), ${ }^{9}$ Derwent et al. (2007b), ${ }^{10}$ Carslaw (2005), ${ }^{11}$ Gigzdiene and Girgzdys (2003), ${ }^{12}$ Brönnimann et al. (2002). 


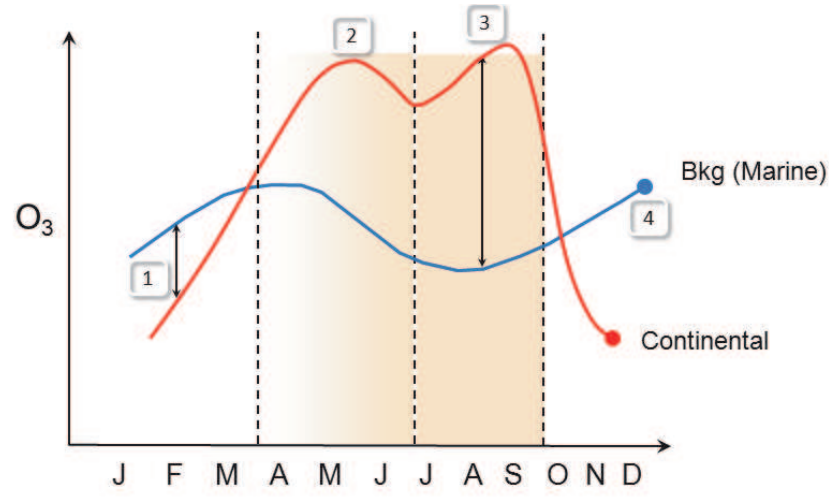

Winter $\mathrm{O}_{3}$ decrement, reduce $\mathrm{NO}_{\mathrm{x}}$ increase $\mathrm{O}_{3}$ Spring Ozone Maximum (see e.g. Monks, 2000)

Summer $\mathrm{O}_{3}$ photochemical increment, reduce $\mathrm{NO}_{x}$, decrease $\mathrm{O}_{3}$ Background $\mathrm{O}_{3}$ seasonal gradient ( $\odot$ ve $\mathrm{O}_{3}$ trend)

Fig. 1. A schematic diagram of an idealized marine background and European continental ozone seasonal cycle.

the hemispheric baseline ozone concentration resulting from global-scale effects, thereby influencing the baseline levels of ozone brought into the UK from the Atlantic Ocean; (ii) substantial short-term elevations in ozone concentrations during summertime episodes, resulting from the formation of additional ozone from regional-scale photochemical processing of emitted VOC and $\mathrm{NO}_{\mathrm{x}}$ over north-west Europe, and (iii) local-scale removal of ozone by direct reaction with emitted NO has gradually decreased, as a result of the control of $\mathrm{NO}_{\mathrm{x}}$ emissions.

Figure 1 is a schematic diagram of an idealized marine background and European continental ozone seasonal cycle. In winter, there is an ozone decrement over continental Europe below the nominal marine background driven by the suppression of ozone levels by NO. In general, reductions in urban $\mathrm{NO}_{\mathrm{x}}$ may lead to an increase in wintertime urban and regional ozone. The origin and occurrence of springtime ozone maximum has been discussed in Monks (2000). In summer, the period of highest photochemical activity there is a substantial ozone increment over marine background controllable by precursor reductions. Seasonal trends can give insight into the relative contribution of photochemical ozone production/peak episodes (summer/95th percentile), $\mathrm{NO}_{\mathrm{x}}$ titration (winter) and the hemispheric background (5th percentile).

Much legislation over the past $20 \mathrm{yr}$, for example the European Directive 2008/50/EC (2008), has focused on the reduction of ozone precursor emissions in Europe. Emission inventories (Monks et al., 2009; Vestreng et al., 2009) show a downward trend in emissions (Fig. 2) in Europe which seems to be matched on the whole by observations of the precursor species (Derwent et al., 2003; EEA, 2007; von Schneidemesser et al., 2010). The mapping of these emission trends to models and observations remains a challenge

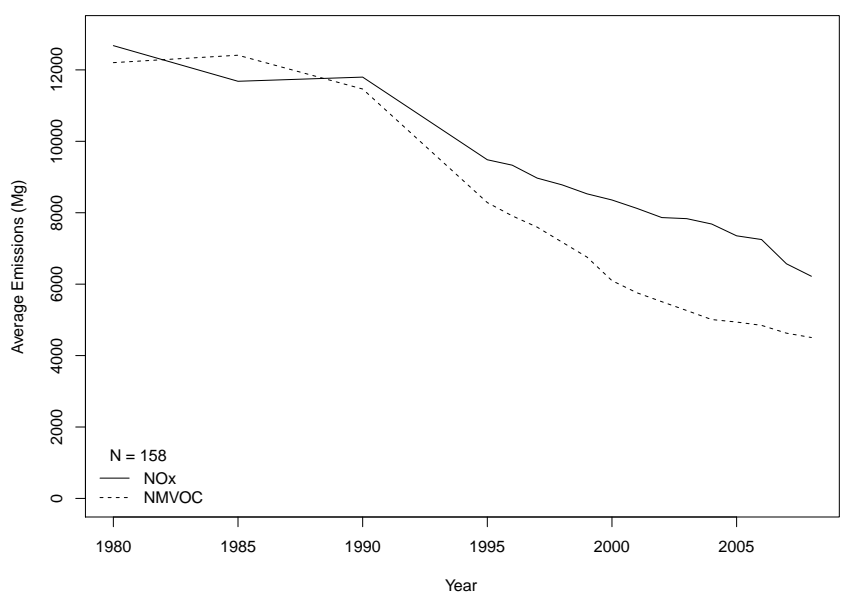

Fig. 2. The average anthropogenic $\mathrm{NO}_{\mathrm{x}}$ and NMVOC emissions (from the EMEP emission inventory) 1980-2008 for the 158 sites used in this study.

(Jonson et al., 2006), particularly the ability to pull out relatively smaller trends from inter-annual variability (Koumoutsaris et al., 2008; Voulgarakis et al., 2010). Derwent et al. (2010) carried out sensitivity studies with a photochemical trajectory model to show how European reductions in VOC and NOx levels would have been the cause of reductions in episodic peak ozone levels. Models (Derwent et al., 2010; Szopa et al., 2006) have also shown that the benefit of European emission control measures can be significantly counterbalanced by increasing background ozone levels and subsequent long range transport, as both are of the same magnitude (up to $4 \mathrm{ppbv}$ ) but opposite in sign coupled to nonlinearities in the photochemical ozone formation. The impact of long-range transport of ozone and its precursors on European ozone concentrations are of significant policy concern (Keating and Zuber, 2007).

The amount of regional-scale work on ozone trends is substantially smaller than that on hemispheric trends. There has been regional-scale work in the USA and Canada (Chan and Vet, 2010; Cooper et al., 2010b; Fiore et al., 2002; Jaffe and Ray, 2007) Japan (Tanimoto et al., 2009), China (Xu et al., 2008) and often on a country-scale within Europe based on a representative site (recent examples in Table 1). There are few studies that have investigated regional scale trends in a self-consistent manner across Europe (see Jonson et al., 2006; Solberg et al., 2009; Vautard et al., 2006).

The work in this paper details observed and modelled regional European ozone trends. A harmonised observational ozone data set from a constant time period of a decade (1996-2005) is used for trend calculation using consistent data analysis techniques. Not only are mean ozone concentrations investigated, but also the ozone 5 th percentiles which can be a measure of the baseline or background conditions, in addition to the 95th percentiles that are representative of 


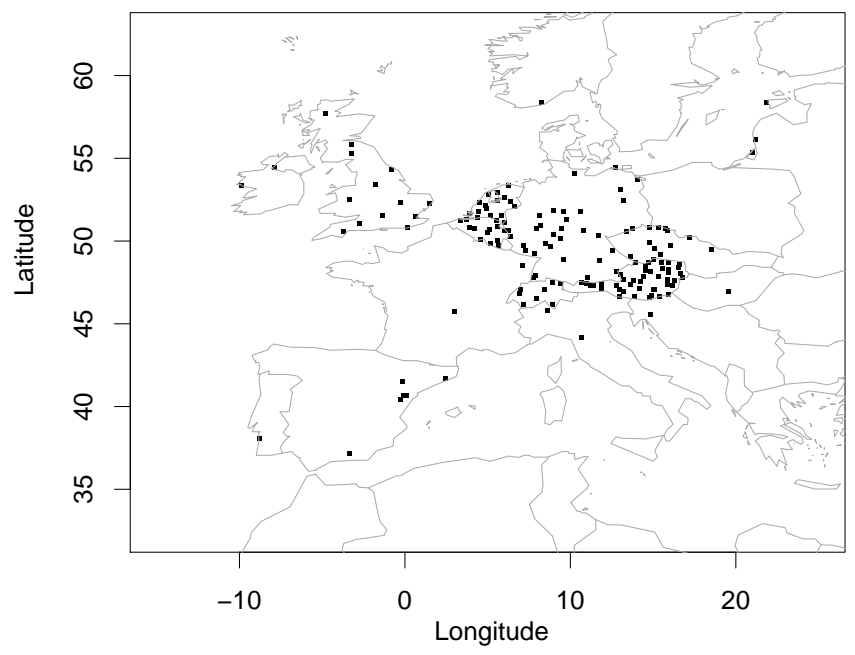

Fig. 3. Locations of the 158 measurement stations used in this study.

the peak concentration levels. Both the annual and seasonal variability are explored to decompose potential photochemical and non-photochemical influences. The study aims to characterise and quantify surface European ozone concentrations and trends and assess the impact of the changing anthropogenic emission tracers on the observed and modelled trends.

\section{Data selection and methodology}

The data used in the trend analysis originates from the the GEOmon project (Global Earth Observation and MONitoring, http://www.geomon.eu/) harmonised data set of trace gases from 397 ground-based measurement stations representative of rural, suburban and urban European environments. These stations belong to a variety of regional, national and European air quality networks (e.g. EMEP, GAW, Airbase and some national network stations).

The harmonised trace gas data set, available from the GEOmon distributed database, provides one ASCII file per site of hourly $\mathrm{O}_{3}, \mathrm{NO}_{2}$ and $\mathrm{CO}$ data covering the time period of 1996-2006 inclusive (http://geomon.nilu.no/). Each file has unified and consistent time stamps in UTC, the conversion of data to units of volume mixing ratio (ppbv), a uniform data flagging system for quality assurance, details of the data source and consistent data formatting to facilitate site comparisons across Europe.

158 sites categorised as rural/background (not directly impacted by nearby precursor emissions), with $\mathrm{O}_{3}$ data available between 1996-2006, were selected for analysis from the overall data set (see Fig. 3 and Table $\mathrm{C} 1$ in the Supplement). The majority of these sites have a continuous time series for the 1996-2005 inclusive period. The selection criteria was a maximum of one year with less than $75 \%$ of data and more than $75 \%$ of the data for all other years.
These sites have been assessed in terms of their representativeness and recategorised accordingly (Henne et al., 2010) (Table $\mathrm{C} 1$ in the Supplement), allowing a characterisation of continental-scale $\mathrm{O}_{3}$ trends. The advantage of this approach at the continental-scale, is the use of a large number of sites which are less influenced by measurement/sampling bias of any single site. The majority of sites are located within central Europe, due to a lack of long-term monitoring sites within France, Spain and the Mediterranean region within the monitoring networks used to compile the GEOmon harmonised dataset. Although the data used within this study may be biased towards Central European locations, the individual sites selected are representative of rural and/or background $\mathrm{O}_{3}$ sites (with the exception of BE0211A, BE0345A, DE0754A, GB0033R, NL0223A, NL0232A that are recategorised as suburban) and are categorised in full within Table C1 in the Supplement.

A variety of tools have been developed to assess the ozone trends using the statistical programming language $\mathrm{R}(\mathrm{R}$ Development Core Team, 2009). Decadal and seasonally disaggregated $\mathrm{O}_{3}$ trends have been characterised using the nonparametric loess regression (Cleveland, 1979) to fit more complex trends of daily and monthly $\mathrm{O}_{3}$ concentrations with at least $75 \%$ data coverage. To identify changes in mean, background and peak $\mathrm{O}_{3}$, the openair package (Carslaw and Ropkins, 2009) was used to deseasonalise $\mathrm{O}_{3}$ time series (using an stl-based method Cleveland et al., 1990), and quantify linear trends (combining the non-parametric MannKendall analysis for trend (Hirsch et al., 1982) with SenTheil slope estimates) of monthly means, 5th and 95th percentiles, respectively. Linear trends were also quantified in units of $\% \mathrm{yr}^{-1}$ from log-transformed (Parrish et al., 2002; Parrish, 2006) data. Annual and seasonal trends are reported including $95 \%$ confidence intervals. The uncertainty of European-averaged annual trends in ozone are reported with $2 \sigma$ errors $\left(\sigma_{T}\right)$ calculated through error propagation from the individual trend uncertainties $\left(\sigma_{t}\right)$ using Equation 1, where $\mathrm{N}$ is the total number of observed sites in this study (158 sites).

$\sigma_{T}=\frac{\sqrt{\Sigma \sigma_{t}^{2}}}{N}$

The statistical uncertainties quoted in this paper must also be convolved with systematic uncertainties typical for the UV absorption measurement of ozone. Generally, $\mathrm{O}_{3}$ data sets of this variety are believed to be accurate to within $\pm 3 \%$.

\section{Results}

There are a number of factors that affect the ability to detect a trend (Weatherhead et al., 1998, 2002) that include:

(a) measurement uncertainty

(b) long-term stability of the measurements 

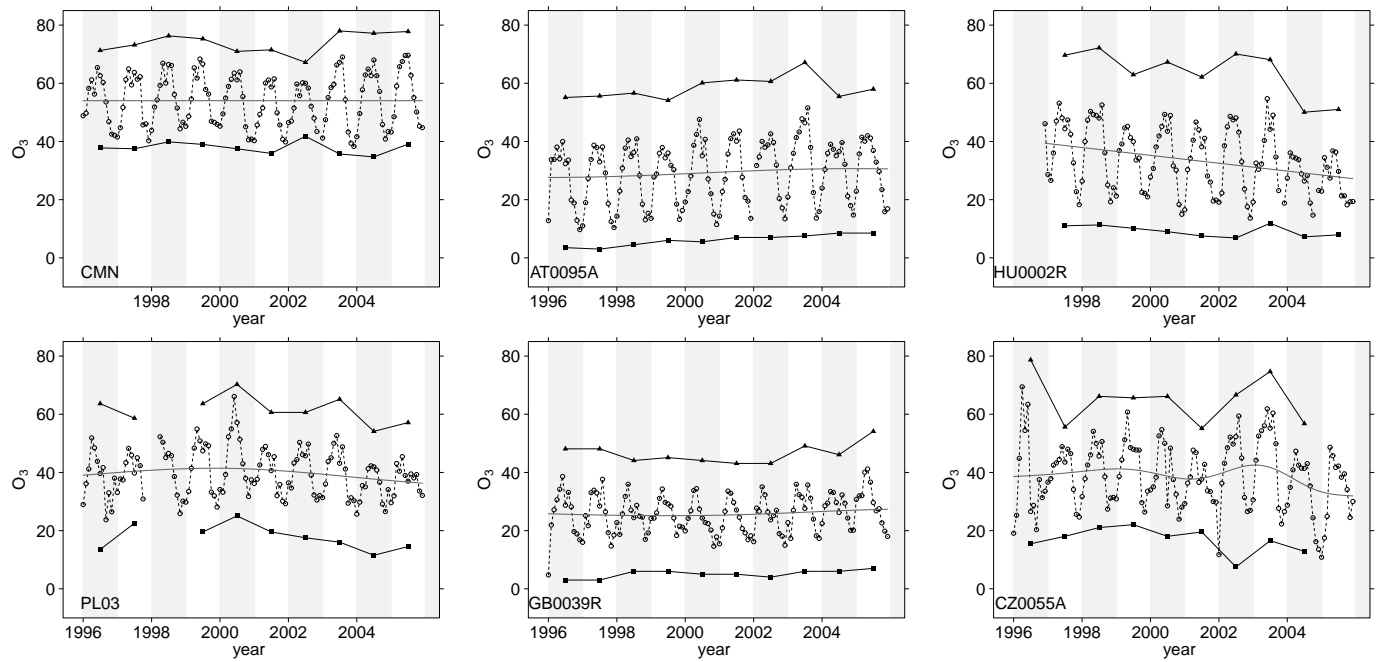

Fig. 4. Examples of categorised loess trends of observed monthly mean $\mathrm{O}_{3}$ ( $\mathrm{ppbv} \mathrm{yr}^{-1}$ ) (all sites available in Fig. A1 of the Supplement) displaying no trend (top left), increasing trend (top middle), decreasing trend (top right), increasing then decreasing trend (bottom left), decreasing then increasing trend (bottom middle right) and a complex trend (bottom right). Circles $=$ monthly mean, squares $=$ annual 5 th percentile, triangle $=$ annual 95 th percentile, grey line $=$ loess trend of monthly mean.

(c) autocorrelation

(d) natural variability

(e) extreme events e.g. heatwaves

In general, the number of years required to detect a trend is dependent on the magnitude of the variance and the autocorrelation coefficient of the noise (Weatherhead et al., 1998).

A number of statistical methods have historically been used to quantify trends in ozone and other environmental datasets, the simplest and most commonly used is a linear regression of which methods are reviewed in Hess et al. (2001). Whilst a loess regression and autoregressive integrated moving average (Tripathi et al., 2010; Oltmans et al., 2008) sometimes combined with a cubic polynomial fit (Oltmans et al., 2008) have been used to highlight and characterise seasonality and longer term variations in ozone timeseries. Trend tests include t-test and Mann-Kendall (Hirsch et al., 1982; Sicard et al., 2009, 2010). Loess regression is a non-parametric method that can be used to derive a good fit and characterisation of complex time-series that have a seasonal component such as ozone, however the trend is not readily quantifiable. Consequently, a Mann-Kendall trend test is used to quantify linear trends over the ten year time period in this study.

In this work an ensemble approach has been developed using 158 sites and may drive the variance down for trend detection but will not offset the influence of meteorological variability. Further, the ensemble is taken from sites that pass the data availability and quality thresholds for this work and has spatial limitations (Fig. 3).

\subsection{Characterisation of annual European ozone trends}

Visual inspection of the loess trends in monthly mean $\mathrm{O}_{3}$ over the period of 1996-2005 (inclusive) show six different forms of temporal evolution (see Fig. 4) namely, (i) no trend, (ii) positive trend, (iii) negative trend, (iv) increasing then decreasing concentrations, (v) decreasing then increasing concentrations and (vi) complex behaviour. Individual plots for all sites are available in Fig. A1 of the Supplement. Each site was categorised accordingly (Table 2, summarised from Table A1 from the Supplement), with the majority (97 sites) exhibiting no apparent loess trends in $\mathrm{O}_{3}$. 30 of the 158 sites exhibit positive $\mathrm{O}_{3}$ loess trends, all of which show increasing annual $\mathrm{O}_{3} 5$ th and/or 95th percentiles. 8 sites, located in eastern, north-eastern and south-western Europe, were characterised with negative $\mathrm{O}_{3}$ loess trends all with declining annual 5th and/or 95 th $\mathrm{O}_{3}$ percentiles. A total of 14 sites were categorised with more complex $\mathrm{O}_{3}$ loess trends, 4 of which are located in the UK.

Quantification of the more simplistic linear trend shows that 85 of the 158 sites, the majority of which are located in north-western and central Europe, display significant $(p<0.1)$ positive linear trends in monthly mean $\mathrm{O}_{3}$ (Fig. 5 and Table A2 in the Supplement), with a range of 0.11 to $1.05 \mathrm{ppbv} \mathrm{yr}^{-1}$ (0.34 to $\left.6.05 \% \mathrm{yr}^{-1}\right)$. Especially high trends are noted in several Austrian sites, with trends of $>1$ ppbv yr $^{-1}$ for AT0154 (Wiesmath) and AT0167 (Payerbach) observed at IT04 (Ispra) located within the Po Valley, a region of high anthropogenic emissions and static meteorology (Finzi and Lechi, 1991; Henne et al., 2010). Significant $(p<0.1)$ negative linear trends in mean $\mathrm{O}_{3}$ are identified at 18 sites, with a range of -0.16 to $-1.28 \mathrm{ppbv} \mathrm{yr}^{-1}$ 

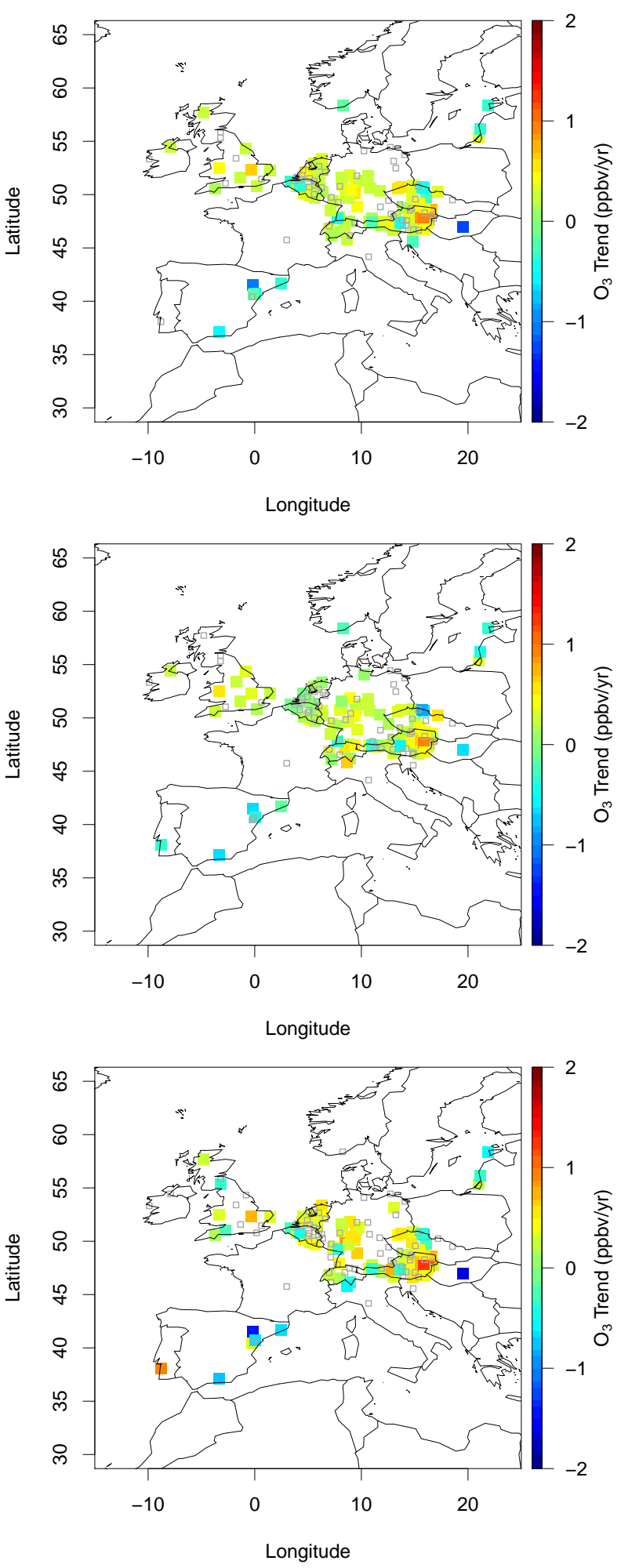

Fig. 5. Spatial distribution of statistically significant annual trends $(p<0.1)$ in observed $\mathrm{O}_{3}$ mean (top), 5th (middle) and 95th (bottom) percentiles. Open squares represent sites with no statistically significant trends.
Table 2. Manual categorisation of $\mathrm{O}_{3}$ time series by loess smoothing. NT - no trend, $\mathrm{P}-$ positive trend, $\mathrm{N}-$ negative trend, $\mathrm{I}+\mathrm{D}$ increasing then decreasing levels, $\mathrm{D}+\mathrm{I}-$ decreasing then increasing levels, $\mathrm{C}$ - complex behaviour.

\begin{tabular}{lccccccc}
\hline $\mathrm{O}_{3}$ Trends & $\mathrm{NT}$ & $\mathrm{P}$ & $\mathrm{N}$ & $\mathrm{I}+\mathrm{D}$ & $\mathrm{D}+\mathrm{I}$ & $\mathrm{C}$ & TOTAL \\
\hline Austria (AT) & 23 & 14 & 0 & 4 & 0 & 2 & 43 \\
Belgium (BE) & 8 & 2 & 0 & 1 & 0 & 0 & 11 \\
Switzerland (CH) & 7 & 0 & 0 & 0 & 0 & 1 & 8 \\
Czech Republic (CZ) & 7 & 3 & 0 & 0 & 0 & 1 & 11 \\
Germany (DE, HPB, ZUG) & 26 & 6 & 1 & 0 & 0 & 1 & 34 \\
Estonia (EE) & 0 & 0 & 1 & 0 & 0 & 0 & 1 \\
France (FR, PUY) & 1 & 0 & 0 & 0 & 0 & 1 & 2 \\
Great Britain (GB) & 4 & 3 & 0 & 2 & 1 & 4 & 14 \\
Hungary (HU) & 0 & 0 & 1 & 0 & 0 & 0 & 1 \\
Ireland (IE) & 1 & 0 & 0 & 0 & 0 & 0 & 1 \\
Italy (IT, CMN) & 2 & 0 & 0 & 0 & 0 & 0 & 2 \\
Lithuania (LT) & 0 & 1 & 0 & 0 & 0 & 0 & 1 \\
Latvia (LV) & 0 & 0 & 0 & 0 & 0 & 1 & 1 \\
Netherlands (NL) & 17 & 1 & 0 & 0 & 0 & 0 & 18 \\
Norway (NO) & 0 & 0 & 1 & 0 & 0 & 0 & 1 \\
Poland (PL) & 0 & 0 & 0 & 1 & 0 & 0 & 1 \\
Portugal (PT) & 0 & 0 & 0 & 0 & 0 & 1 & 1 \\
Spain (ES) & 1 & 0 & 3 & 0 & 0 & 2 & 6 \\
Slovinia (SI) & 0 & 0 & 1 & 0 & 0 & 0 & 1 \\
\hline TOTAL & 97 & 30 & 8 & 8 & 1 & 14 & 158 \\
\hline
\end{tabular}

$\left(-0.45\right.$ to $\left.-4.11 \% \mathrm{yr}^{-1}\right)$. The greatest reduction is observed at HU0002R (K-puszta). The linear trends calculated for the remaining 55 sites, located throughout Europe, are not statistically significant $(p>0.1)$. The European-averaged annual trend in mean $\mathrm{O}_{3}$ is $0.16 \pm 0.02 \mathrm{ppbv} \mathrm{yr}^{-1}$ ( $2 \sigma$ error), with a total range of -1.28 to $1.05 \mathrm{ppbv} \mathrm{yr}^{-1}$.

The low percentiles in an ozone distribution can be representative of the influence of "background" ozone, or be a result from a decreasing trend in removal by reaction with locally emitted NO (for example see Jenkin, 2008). Often these two effects have different seasonal patterns as during winter shallow inversion layers can cause elevated $\mathrm{NO}_{\mathrm{x}}$ concentrations, even at rural sites. Previous work (Lindskog et al., 2003) with $\mathrm{NO}_{\mathrm{x}}$ integrated trajectories has shown a decrease in the winter ozone deficit across Europe. Examination of $\mathrm{O}_{3}$ 5th percentiles demonstrates that 82 of the 158 sites in central and north-western Europe have significant $(p<0.1)$ positive linear trends. The range across those sites with a positive significant trends was 0.00 to $0.98 \mathrm{ppbv} \mathrm{yr}^{-1}(0.00$ to $20.02 \% \mathrm{yr}^{-1}$, rounded to 2 decimal places) (see Fig. 5 and Table A3 in the Supplement). The highest trends in ozone 5th percentiles are seen in several Austrian sites, with trends of $0.98 \mathrm{ppbv} \mathrm{yr}^{-1}$ for AT0154 (Wiesmath) and AT0167 (Payerbach). These findings are similar to the increasing background trends identified in baseline $\mathrm{O}_{3}$ in north-west European and Alpine regions (including sites in Ireland, Scotland, Norway, Sweden, Finland and high altitude sites) between the early 1990s to early 2000s (Lindskog et al., 2003) and are consistent with observations across the Northern Hemisphere (Carslaw (2005); Vingarzan (2004) and references therein). Similar to the annual mean $\mathrm{O}_{3}$ trends, the largest 
trend of the 5th percentiles, in terms of percentage increase per year, is observed at IT04 (Ispra), which is influenced by the extremely low $\mathrm{O}_{3}$ levels ( $<2 \mathrm{ppbv}$ ) at the beginning of the measurement period attributed to NO titration in stagnant air masses. Therefore, emission reductions most likely caused this trend.

19 of the 158 sites typically in the outermost locations of Europe, some near-coastal, display significant $(p<0.1)$ negative trends in $\mathrm{O}_{3}$ 5th percentiles, with a range of -0.03 to $-0.88 \mathrm{ppbv} \mathrm{yr}^{-1}\left(-0.67\right.$ to $\left.-6.32 \% \mathrm{yr}^{-1}\right)$. A total of 57 of the 158 sites have linear trends that are not statistically significant, suggesting that low percentile $\mathrm{O}_{3}$ may not have substantially changed at these sites between 19962005. The European annual trend in $\mathrm{O}_{3}$ 5th percentiles is

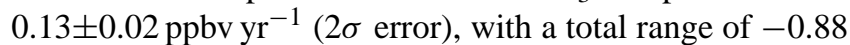
to $0.98 \mathrm{ppbv} \mathrm{yr}^{-1}$.

Figure 5 (compiled from Table A4 within the Supplement) illustrates that significant $(p<0.1) 1996-2005 \mathrm{O}_{3}$ 95th percentile linear trends are positive across 71 of the 158 sites predominantly in central, north-western and western Europe, with a range of 0.15 to $1.21 \mathrm{ppbv} \mathrm{yr}^{-1}\left(0.24\right.$ to $\left.2.16 \% \mathrm{yr}^{-1}\right)$. Peak ozone values and their trends are often taken as evidence for the number and frequency of photochemically induced events (see for example Jenkin, 2008). Just 19 of the 158 sites scattered throughout Europe display negative linear trends $(p<0.1)$, with a range of -0.21 to $-1.62 \mathrm{ppbv} \mathrm{yr}^{-1}$ $\left(-0.38\right.$ to $\left.-3.12 \% \mathrm{yr}^{-1}\right)$, consistent with previous analyses of sites in the United Kingdom, Denmark, Norway, Sweden, Netherlands, Germany, Switzerland and Lithuania which showed a decrease in peak (95th or 98th percentiles) $\mathrm{O}_{3}$ levels from the early 1990's to early 2000's (Lindskog et al., 2003; Jenkin, 2008; Brönnimann et al., 2002). Furthermore, 68 of the 158 sites throughout Europe display trends that were not statistically significant, suggesting that $\mathrm{O}_{3}$ levels at these sites may not have substantially altered during the period. The European annual trend in $\mathrm{O}_{3}$ 95th percentiles is $0.16 \pm 0.03 \mathrm{ppbv} \mathrm{yr}^{-1}$ (including $2 \sigma$ error propagation), with a total range of -1.62 to $1.21 \mathrm{ppbv} \mathrm{yr}^{-1}$. It is interesting to note that these observations on the surface seem to contradict the perceived wisdom that emission reductions across Europe have reduced peak ozone levels.

\subsection{Testing the influence of individual years in the annual trend}

To establish how the overall annual ozone trend calculated in this study is affected by the data from any given year, the influence of individual years on the the annual trend in the 1996-2005 time period has been investigated. Table 3 summarises the European-averaged trends (using all 158 sites, $2 \sigma$ error) for $\mathrm{O}_{3}$ mean, 5th and 95th percentiles when data from one year is systematically excluded. The deviation from the European-averaged annual trends for mean, 5th and 95th percentiles are given in Fig. 6. The removal of individual years 1997, 1998 and 1999 from the trend analysis result

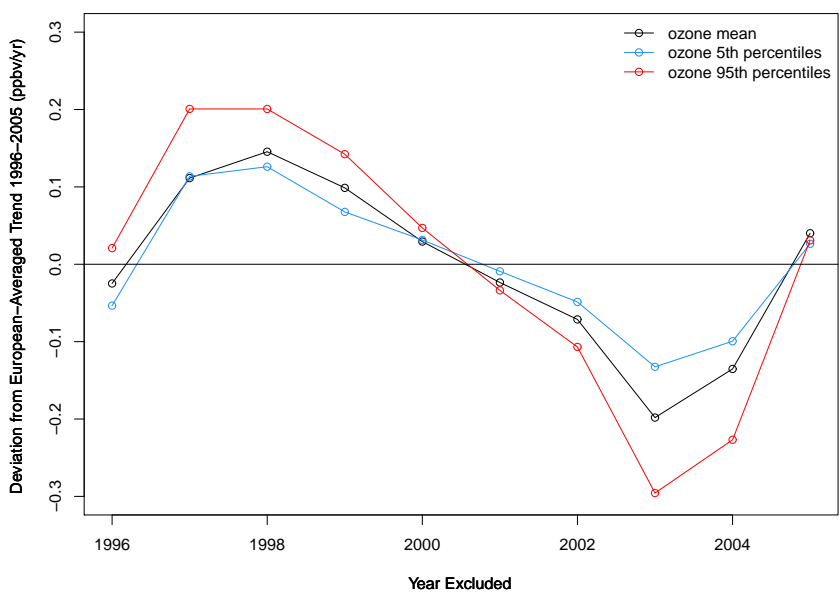

Fig. 6. The deviation from the 1996-2005 inclusive Europeanaveraged annual trend in mean, 5th and 95thpercentiles when individual years are excluded from analysis.

in higher magnitude overall positive trends, with a greater proportion of statistically significant $(p<0.1)$ sites showing positive trends. In contrast, the removal of data from 2003 or 2004 respectively from the trend analysis has a profound influence resulting in negative overall annual trends in $\mathrm{O}_{3}$ 95th percentiles. A lower number of sites exhibit significant trends, of these a higher proportion of sites exhibit negative annual trends in $\mathrm{O}_{3}$ mean, 5th and 95th percentiles if 2003 or 2004 are excluded from analysis.

Despite using $10 \mathrm{yr}$ time series for trend analysis, interannual and extreme variation of meteorological and climatological conditions can have a strong influence on trends during the selected time period (Jonson et al., 2006). Visual inspection of the $\mathrm{O}_{3}$ time-series (available in the Supplement in Fig. A1) highlights that many sites exhibit unusually high $\mathrm{O}_{3}$ levels in 1997-1998 and/or 2003. A number of phenomena occurred during these time periods that could have had a substantial influence on the observed $\mathrm{O}_{3}$ concentrations. The relatively high $\mathrm{O}_{3}$ monthly means in 1998/1999 have been linked to large-scale global biomass burning, in conjunction with an El Niño event between 1997-1998 (Simmonds et al., 2004). Similarly, Jaffe et al. (2004) identified that Siberian biomass burning in the summer of 2003 contributed to increases in background $\mathrm{O}_{3}$ of 5-9 ppbv at ten sites in the northern hemisphere. Additionally, the European heatwave during the summer of 2003 is a contributory factor leading to high $\mathrm{O}_{3}$ levels that year (Solberg et al., 2008; Lee et al., 2006; Ordóñez et al., 2005). With European summer heat waves recorded more frequently in recent years (i.e. 2003, 2006, 2007 and 2010), these extreme meteorological/climatological conditions will influence $\mathrm{O}_{3}$ levels and trends during this time period, potentially masking the effect of emissions reductions on the production of secondary pollutants such as $\mathrm{O}_{3}$ (Solberg et al., 2008). 
Table 3. A summary of European-averaged trends (where $N=158$ sites) in $\mathrm{O}_{3}$ mean, 5th and 95th percentiles during the period 1996-2005 with the exclusion of data from individual years. $N(+)$ and $N(-)$ the number of sites with significant $(p<0.1)$ positive and negative trends respectively. Bold text highlights those years with high influence on trends during the overall 1996-2005 period, see text for details.

\begin{tabular}{c|ccc|ccc|ccc}
\hline $\begin{array}{c}\text { Excluded } \\
\text { Year }\end{array}$ & $\begin{array}{c}\text { Trend } \\
\text { Mean }\end{array}$ & $\begin{array}{c}N \\
(+)\end{array}$ & $\begin{array}{c}N \\
(-)\end{array}$ & $\begin{array}{c}\text { Trend } \\
5 \text { th Percentile }\end{array}$ & $\begin{array}{c}N \\
(+)\end{array}$ & $\begin{array}{c}N \\
(-)\end{array}$ & $\begin{array}{c}\text { Trend } \\
95 \text { th Percentile }\end{array}$ & $\begin{array}{c}N \\
(+)\end{array}$ & $\begin{array}{c}N \\
(-)\end{array}$ \\
\hline 1996 & $0.14 \pm 0.02$ & 64 & 18 & $0.08 \pm 0.02$ & 56 & 21 & $0.18 \pm 0.03$ & 65 & 17 \\
1997 & $\mathbf{0 . 2 7} \pm \mathbf{0 . 0 2}$ & $\mathbf{1 0 4}$ & $\mathbf{1 5}$ & $\mathbf{0 . 2 4} \pm \mathbf{0 . 0 2}$ & $\mathbf{1 0 4}$ & $\mathbf{1 9}$ & $\mathbf{0 . 3 6} \pm \mathbf{0 . 0 3}$ & $\mathbf{1 0 1}$ & $\mathbf{1 1}$ \\
1998 & $\mathbf{0 . 3 1} \pm \mathbf{0 . 0 2}$ & $\mathbf{1 0 9}$ & $\mathbf{4}$ & $\mathbf{0 . 2 6} \pm \mathbf{0 . 0 2}$ & $\mathbf{1 0 4}$ & $\mathbf{8}$ & $\mathbf{0 . 3 6} \pm \mathbf{0 . 0 3}$ & $\mathbf{9 6}$ & $\mathbf{4}$ \\
1999 & $\mathbf{0 . 2 6} \pm \mathbf{0 . 0 2}$ & $\mathbf{1 0 7}$ & $\mathbf{1 1}$ & $\mathbf{0 . 2 0} \pm \mathbf{0 . 0 2}$ & $\mathbf{9 7}$ & $\mathbf{1 3}$ & $\mathbf{0 . 3 0} \pm \mathbf{0 . 0 3}$ & $\mathbf{9 5}$ & $\mathbf{6}$ \\
2000 & $0.19 \pm 0.02$ & 86 & 15 & $0.16 \pm 0.02$ & 84 & 16 & $0.21 \pm 0.03$ & 68 & 14 \\
2001 & $0.14 \pm 0.02$ & 67 & 17 & $0.12 \pm 0.02$ & 72 & 22 & $0.13 \pm 0.03$ & 51 & 19 \\
2002 & $0.09 \pm 0.02$ & 53 & 19 & $0.08 \pm 0.02$ & 62 & 23 & $0.05 \pm 0.03$ & 34 & 24 \\
2003 & $-\mathbf{0 . 0 4} \pm \mathbf{0 . 0 2}$ & $\mathbf{2 5}$ & $\mathbf{2 8}$ & $\mathbf{0 . 0 0} \pm \mathbf{0 . 0 2}$ & $\mathbf{3 8}$ & $\mathbf{3 3}$ & $-\mathbf{0 . 1 4} \pm \mathbf{0 . 0 3}$ & $\mathbf{1 3}$ & $\mathbf{4 4}$ \\
2004 & $\mathbf{0 . 0 2} \pm \mathbf{0 . 0 2}$ & $\mathbf{4 1}$ & $\mathbf{2 5}$ & $\mathbf{0 . 0 3} \pm \mathbf{0 . 0 2}$ & $\mathbf{4 5}$ & $\mathbf{3 1}$ & $-\mathbf{0 . 0 7} \pm \mathbf{0 . 0 3}$ & $\mathbf{2 3}$ & $\mathbf{3 7}$ \\
2005 & $0.20 \pm 0.02$ & 91 & 16 & $0.16 \pm 0.02$ & 82 & 13 & $0.19 \pm 0.03$ & 16 & 17 \\
\hline none & $0.16 \pm 0.02$ & 85 & 18 & $0.13 \pm 0.02$ & 82 & 19 & $0.16 \pm 0.03$ & 71 & 19 \\
\hline
\end{tabular}

It is apparent that 1998 and 2003 are pivotal years during the 1996-2005 $\mathrm{O}_{3}$ trend analysis period. Furthermore, we show that meteorological events in a single month (i.e. August 2003 heatwave) can be sufficient to alter the sign of the trend in a ten year time period. Zvyagintsev and Tarasova (2011) similarly identified that changes in relative humidity and in temperature at eight German sites decreased the ozone trends by $0.5-1.0 \mathrm{ppb}$ per $10 \mathrm{yr}$ in the time periods analysed (11 to $16 \mathrm{yr}$ ), with a significant proportion of $\mathrm{O}_{3}$ trends (up to several tens of percent) attributed to trends of these meteorological variables. Investigating trends in significantly longer time-series would be required to limit the effects of such years containing unusually high $\mathrm{O}_{3}$ levels as a result of extreme meteorological/climatological conditions. Weatherhead et al. (1998) calculate that 30-35 yr of monthly mean data is required to detect a trend of $5 \%$ per decade $\left(0.25 \mathrm{ppbv} \mathrm{yr}^{-1}\right)$ at a $95 \%$ confidence level for a species such as tropospheric $\mathrm{O}_{3}$. There are only a limited number of European measuring sites with long $\mathrm{O}_{3}$ time-series of $20 \mathrm{yr}$ or more, these are presently not temporally harmonised to offer spatial coverage across Europe. It is necessary that the monitoring of trace gas measurements across Europe is continued in order to provide the lengthy time-series required for future trace gas trend analysis on a regional scale, without the masking by meteorological and background ozone variabilities.

Statistical approaches to account for the effects of meteorological variables on tropospheric $\mathrm{O}_{3}$ trends has been discussed extensively in Thompson et al. (2001). More recently, the approach of using a generalised additive model (Stephan Henne, personal communication) or a generalized linear mixed model (Chan, 2009) to remove part of $\mathrm{O}_{3}$ variability that can be explained by meteorology provides a clearer indication of $\mathrm{O}_{3}$ trends resulting from emission reduction measures.

\subsection{The characterisation and quantification of seasonal European ozone trends}

In order to further investigate the different contributions to the observed ozone trends, seasonal variations of monthly mean, 5th and 95th percentiles of $\mathrm{O}_{3}$ for 1996-2005 have been calculated for spring (MAM), summer (JJA), autumn (SON) and winter (DJF). Figure 7 shows typical seasonal cycles for 4 sites (available in full in Fig. A2 within the Supplement). The nature of the shape and form of ozone seasonal cycles has been discussed by Monks (2000). For example, the seasonal cycles in northern, north-western and western European sites (Great Britain, Ireland, Norway and Portugal) display a spring maximum (or summer minimum), with $\mathrm{O}_{3}$ peaking typically in April or May. There has been much debate as to the controlling features of ozone seasonal cycles (see for example Monks (2000) and references therein) and the relative contributions of in-situ photochemistry, deposition, stratospheric/tropospheric exchange.

In the case of $\mathrm{O}_{3} 5$ th percentiles, sites in peripheral Europe display a spring time maximum, whilst those in more central locations exhibit either a secondary summer maximum or a broad spring-summer maximum. GB0006R (Lough Navar) and IE31 (Mace Head) display spring maxima in $\mathrm{O}_{3}$ 95th percentiles, consistent with the influence of marine air received at these sites, which is not strongly affected by locally emitted human induced $\mathrm{O}_{3}$ precursors. The same sort of feature in baseline ozone has been observed in continental Canada (Chan and Vet, 2010). All other sites display either a secondary summer maximum or a broad spring-summer maximum in the 95 th percentiles.

Relatively few sites display statistically significant $(p<0.1)$ linear trends in Winter (19 sites), spring (31 sites), summer (30 sites) or Autumn (10 sites) mean $\mathrm{O}_{3}$. Of those that are statistically significant, many show positive trends 

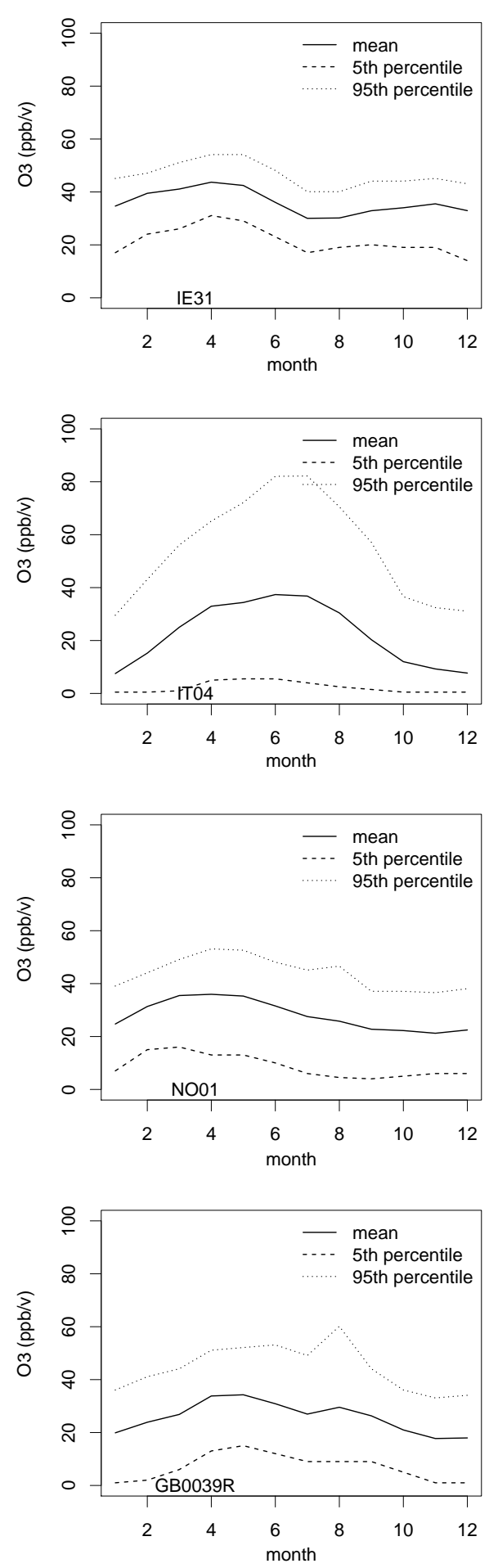

Fig. 7. Examples of seasonal cycles from IE31 [Mace Head], IT04 [Ispra], NO01 [Birkenes] and GB0039R [Sibton] showing from top to bottom examples of a spring maximum, broad spring-summer maximum, spring maximum with secondary summer maximum in 95th percentile and a spring and summer maxima in mean, 5th and 95th percentiles. All sites are available in Fig. A2 of the Supplement. in winter (17 sites), spring (27 sites) and summer (23 sites) ( 0.3 to $1.31 \mathrm{ppbv} \mathrm{yr}^{-1}, 0.28$ to $1.65 \mathrm{ppbv} \mathrm{yr}^{-1}$ and 0.37 to $1.15 \mathrm{ppbv} \mathrm{yr}^{-1}$, respectively). Additionally, there are negative trends at a small number of sites in winter (ES1437A and ZUG), spring (EE0011R, HU0002R and NO01), summer (CZ0001R, DE0009R, DE0684A, DE0754A, HU0002R and LV0010R) and autumn (BE0033R, HU0002R, LV0010R, SI0008R and ZUG) of -0.4 to $-0.72 \mathrm{ppbv} \mathrm{yr}^{-1},-0.15$ to $-1.88 \mathrm{ppbv} \mathrm{yr}^{-1},-0.40$ to $-1.27 \mathrm{ppbv} \mathrm{yr}^{-1}$ and -0.46 to $-1.60 \mathrm{ppbv} \mathrm{yr}^{-1}$, respectively.

A greater number of sites display statistically significant $(p<0.1)$ linear trends of $\mathrm{O}_{3} 5$ th percentiles in winter (43 sites), spring (34 sites), summer (44 sites) or autumn (26 sites) than for the respective seasonal mean $\mathrm{O}_{3}$. Of these sites, many show positive trends in winter (33 sites), spring (29 sites) and summer ( 33 sites) ( 0.09 to $1.30 \mathrm{ppbv} \mathrm{yr}^{-1}, 0.06$ to $1.65 \mathrm{ppbv} \mathrm{yr}^{-1}$ and 0.04 to $1.15 \mathrm{ppbv} \mathrm{yr}^{-1}$, respectively). Negative trends are observed at a number of sites in winter (10 sites, 6 of which are in Spain), spring (5 sites), summer (11 sites) and autumn (19 sites) with a range of -0.12 to $-1.01 \mathrm{ppbv} \mathrm{yr}^{-1},-0.02$ to $-1.88 \mathrm{ppbv} \mathrm{yr}^{-1},-0.20$ to $-1.27 \mathrm{ppbv} \mathrm{yr}^{-1}$ and -0.08 to $-1.60 \mathrm{ppbv} \mathrm{yr}^{-1}$ respectively. The seasonal linear trends in $\mathrm{O}_{3}$ 5th percentiles tend to be of the greatest magnitude during winter and spring, suggesting these have the most influence on the typically increasing annual trends in 5th percentiles of $\mathrm{O}_{3}$.

Very few sites display statistically significant $(p<0.1)$ linear trends of $\mathrm{O}_{3}$ 95th percentiles in winter (18 sites), spring (19 sites), summer (28 sites) or autumn (11 sites) (available in full in Table A7 in Supplement). Of these, many show positive trends in winter (15 sites), spring (18 sites) and summer (18 sites) $\left(0.25\right.$ to $1.30 \mathrm{ppbv} \mathrm{yr}^{-1}, 0.24$ to $1.65 \mathrm{ppbv} \mathrm{yr}^{-1}$ and 0.26 to $1.15 \mathrm{ppbv} \mathrm{yr}^{-1}$, respectively), with the highest magnitude often exhibited in summer at a time of maximum photochemistry, consequently having the largest influence on annual trends in 95th percentiles of $\mathrm{O}_{3}$. Negative trends are observed at a number of sites in winter ( 3 sites), spring ( 2 sites), summer (10 sites) and particularly autumn (10 sites) with values of -0.41 to $-0.70 \mathrm{ppbv} \mathrm{yr}^{-1},-1.22$ to $-1.88 \mathrm{ppbv} \mathrm{yr}^{-1}$, -0.07 to $-1.30 \mathrm{ppbv} \mathrm{yr}^{-1}$ and -0.37 to $-2.94 \mathrm{ppbv} \mathrm{yr}^{-1}$ respectively.

An average European seasonal cycle 1996-2005 (inclusive), calculated using all sites from this study shows a broad spring-summer maximum in mean $\mathrm{O}_{3}$ (Fig. 8), with a secondary summer maximum. This summer maximum is most dominant in the $\mathrm{O}_{3}$ 95th percentile seasonal cycle, peaking in August when there is increased photochemical activity. The European averages of both seasonal and annual trends have been calculated and included on Fig. 8 using the data from all 158 sites. Averaged across Europe, trends in $\mathrm{O}_{3}$ 5th and 95th percentiles are positive during winter, spring and summer. The greatest magnitudes are observed in winter 5th $\left(0.26 \pm 0.07 \mathrm{ppbv} \mathrm{yr}^{-1}, 2 \sigma\right.$ error $)$ and spring for both $\mathrm{O}_{3}$ 5 th and 95th percentiles, with values of $0.24 \pm 0.05 \mathrm{ppbv} \mathrm{yr}^{-1}$ and $0.31 \pm 0.09 \mathrm{ppbv} \mathrm{yr}^{-1}$ respectively. Autumn trends in 


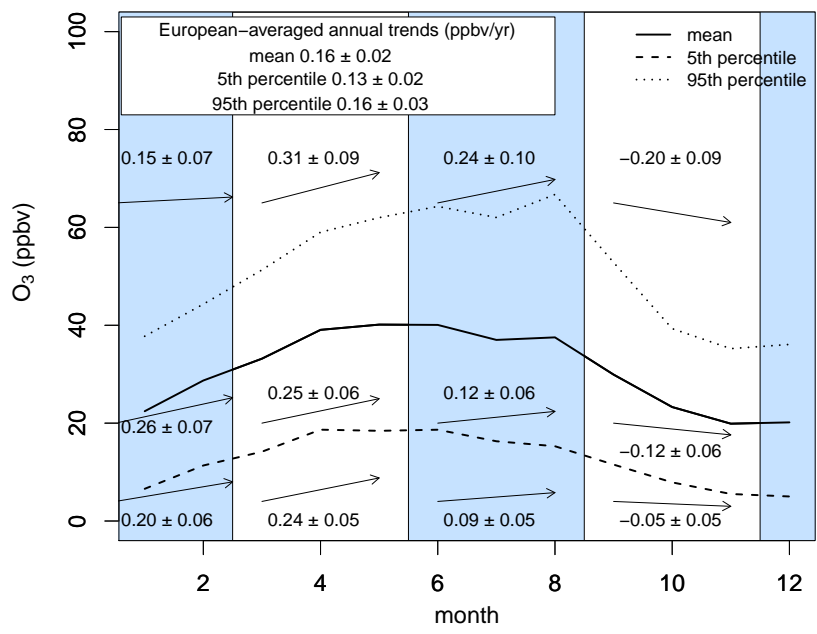

Fig. 8. The average European seasonal $\mathrm{O}_{3}$ cycle for mean, 5th and 95th percentiles. Annotations display the statistically significant $(p<0.1)$ European-averaged seasonal (winter, spring summer,

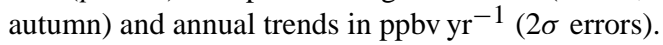

both 5th and 95th percentiles are negative with values of $-0.05 \pm 0.05 \mathrm{ppbv} \mathrm{yr}^{-1}$ and $-0.20 \pm 0.09 \mathrm{ppbv} \mathrm{yr}^{-1}$ respectively.

\section{Trends in emissions as represented in inventories}

In order to explore the factors driving the observed ozone trends, the trends in the corresponding emission inventories for the anthropogenic ozone precursors have been examined. Trend analysis of EMEP anthropogenic $\mathrm{NO}_{\mathrm{x}}$ and VOC emissions (Vestreng et al., 2006) (available at http: //www.ceip.at/) for Europe during the observation period 1996-2005 are shown in Fig. 9. For scaling purposes, only statistically significant $(p<0.1)$ trends between -10 to $10 \% \mathrm{yr}^{-1}$ are displayed on the maps. In the emission inventory data the majority of Europe show negative trends in excess of $-3.00 \% \mathrm{yr}^{-1}$ in $\mathrm{NO}_{\mathrm{x}}$ and $\mathrm{VOC}$ emissions, consistent with with $\mathrm{NO}_{\mathrm{x}}$ emissions trends calculated for 1996-2005 by Konovalov et al. (2008) who determined reductions of $-4.7 \pm 0.6 \% \mathrm{yr}^{-1},-3.7 \pm 0.7 \% \mathrm{yr}^{-1}$ and $-2.8 \pm 1.3 \% \mathrm{yr}^{-1}$ for Great Britain, Germany and France respectively. These reductions are thought to be influenced by the introduction of European legislation and the mandatory use of catalytic converters in vehicles (Monks et al., 2009; Vestreng et al., 2009). Spain and Portugal display positive trends in NOx, with the Iberian and Italian coasts highlighting high positive $\mathrm{NO}_{\mathrm{x}}$ trends of up to $10.00 \% \mathrm{yr}^{-1}(p<0.1)$. These coastal regions are affected by the Atlantic and Mediterranean shipping tracks (Konovalov et al., 2008). Positive $\mathrm{NO}_{\mathrm{x}}$ trends are also noted in Austria and Hungary which may be linked to the economic recovery of Eastern European countries since the late 1990's (Vestreng et al., 2009). VOC emissions across
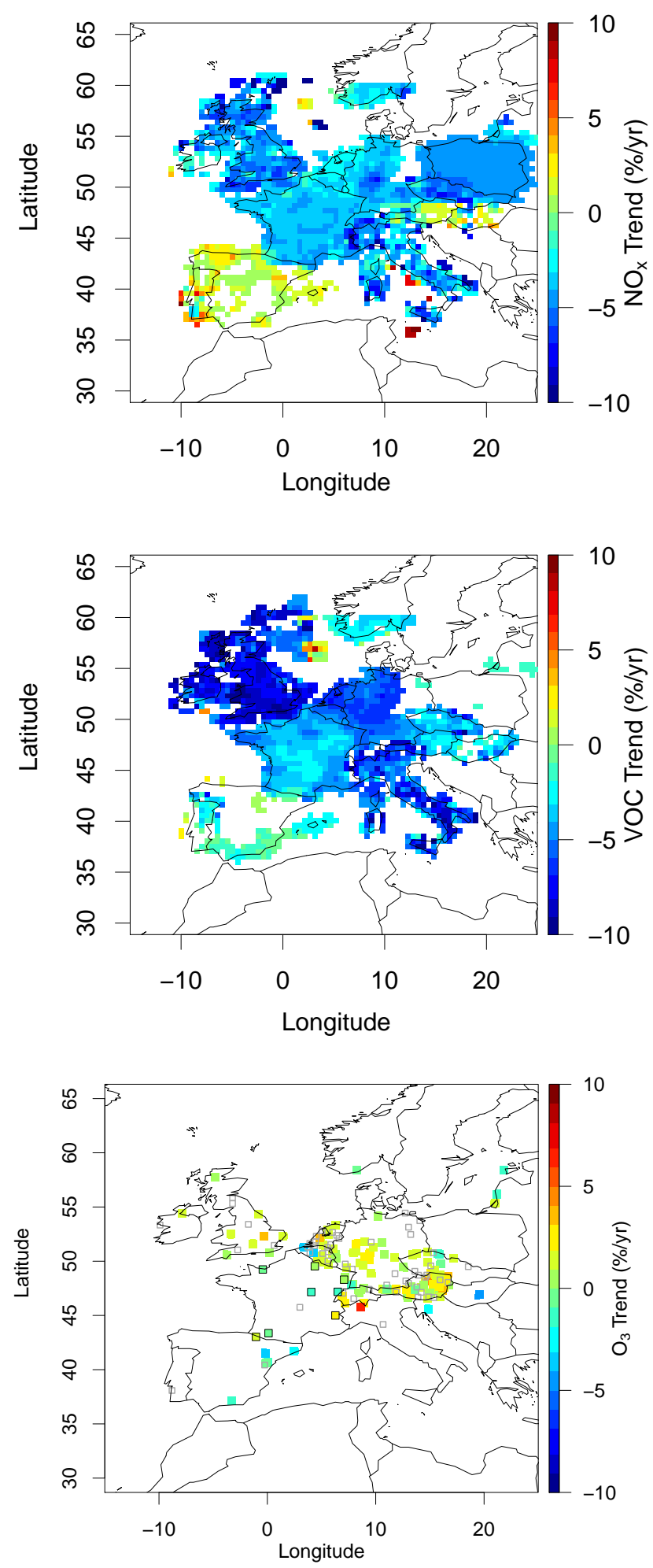

Fig. 9. Spatial distribution of significant $(p<0.1)$ annual trends (between -10 to $10 \% \mathrm{yr}^{-1}$ ) in $\mathrm{NO}_{\mathrm{x}}$ (top), VOCs (middle) (both from the EMEP emission inventory, see text for details) and mean $\mathrm{O}_{3}$ (bottom) 1996-2005 inclusive. Open squares = sites with no statistically significant trends, black lined squares are $\mathrm{O}_{3}$ surface data 1995-2003 included from Sicard et al. (2009). 


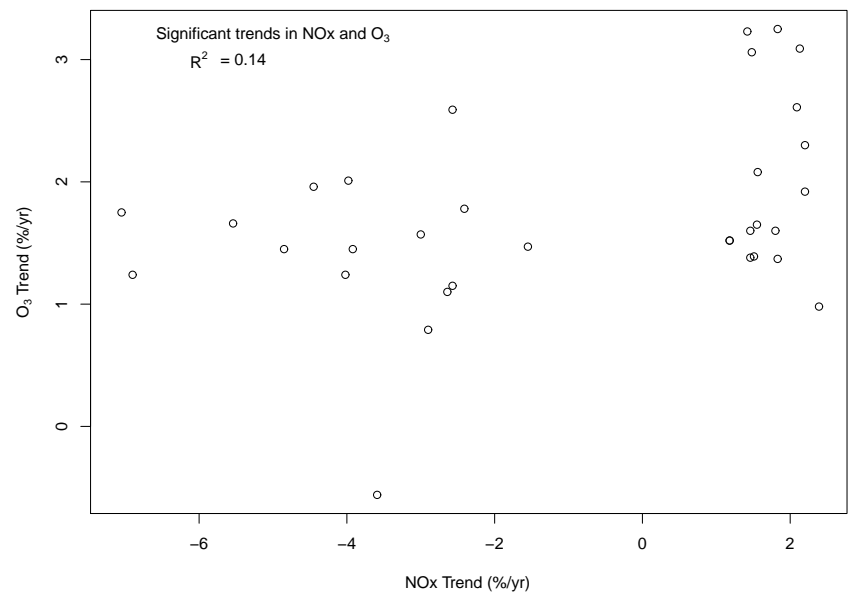

Fig. 10. Correlation of statistically significant annual trends in $\mathrm{NO}_{\mathrm{x}}$ (from the EMEP emission inventory, see text for details) and observed $\mathrm{O}_{3}$ (40 sites).

Europe have decreased with the exception of North Sea fossil fuel sites and the Iberian peninsula.

Trends in $\mathrm{O}_{3}\left(\% \mathrm{yr}^{-1}\right)$ are also given in Fig. 9, including those from French sites between 1995-2003 (Sicard et al., 2009), which are consistent with trends from sites within this study. Comparing observed $\mathrm{O}_{3}$ and anthropogenic emissions, the Austrian sites show a record of positive trends in $\mathrm{NO}_{\mathrm{x}}$ and observed $\mathrm{O}_{3}$ trends in addition to negative trends in VOC emissions between 1996-2005 (Fig. 9). In contrast, Spanish sites display positive trends in NOx, whilst negative trends in VOCs and observed $\mathrm{O}_{3}$. Anthropogenic $\mathrm{NO}_{\mathrm{x}}$ (see Fig. 10) and VOC reductions appear to be uncorrelated to $\mathrm{O}_{3}$ annual trends in the rest of Europe (Fig. 9), suggesting precursor emissions may not have as directly related an effect on $\mathrm{O}_{3}$ formation at these sites. Consideration must also be given to meteorological conditions, chemical reactions (e.g. $\mathrm{NO}_{\mathrm{x}}$ titration) and the trans-boundary transport of ozone and its precursors to the measurement sites.

\section{A comparison with a regional chemical transport model}

In order to investigate the impact of emission reductions on a regional scale for comparison to observed measurements, simulated $\mathrm{O}_{3}$ from the CHIMERE chemical transport model was analysed. CHIMERE (Schmidt et al., 2001) was used to generate simulated $\mathrm{O}_{3}$ concentrations for a regional domain including Europe, with a horizontal resolution of $1^{\circ} \times 1^{\circ}$. The boundary conditions used are monthly varying climatologies calculated by averaging multi-year simulation (1999-2005) of the LMDZ-INCA climate-chemistry model. Therefore the boundary conditions reflect an annual cycle of background pollutants. In this work, the model considers only the evolution of meteorological conditions and emissions. The bound- ary conditions do not account for the year to year variability nor for global trends. However, as shown by Vautard et al. (2006), an imposed trend in boundary conditions does not improve the skills of CHIMERE to reproduce the observed trends. For these reasons and because there was no global climatology consistent and continuous over the 1990-2008 time period available at the time we did this simulation, we do not consider the long-term boundary condition variations. Emission inventories were taken from EMEP (Vestreng et al., 2006) (see Sect. 4 for details of trends in this emission inventory). Hourly concentrations of $\mathrm{O}_{3}$ of each year 1996-2005 (inclusive) were extracted from grid squares closest to the site locations given in Table $\mathrm{C} 1$ of the Supplement and assigned to these sites.

Loess regression and linear regression (available in full in Appendix B Fig. B1 and Tables B1-B3 of the Supplement) of annual mean, 5th and 95th percentiles have characterised and quantified trends in CHIMERE simulated $\mathrm{O}_{3}$ with data extracted for the 158 locations of measurement sites used in this study. Figure 11 gives examples of the CHIMERE monthly means from six sites, with the corresponding observed sites from Fig. 4. From a visual inspection, CHIMERE time-series are of the similar magnitude and variability as the observed $\mathrm{O}_{3}$ time-series, with the exception of some high altitude sites. As CHIMERE $\mathrm{O}_{3}$ concentrations were extracted from the surface layer of the model, this may explain the differences between the minimum $\mathrm{O}_{3}$ levels in the model and observed time-series (Fig. 11) as a result of surface deposition in the model, but not at the elevated site. These six sites were representative of different loess trends categorised manually from a visual inspection of the observed data (Fig. 4). However, the loess trends of the CHIMERE monthly mean $\mathrm{O}_{3}$ from equivalent sites are more static, showing no apparent trend.

Despite the limited sites with statistically significant trends $(p<0.1)$, annual trends in mean $\mathrm{O}_{3}$ tend to be positive with a range of 0.09 to $0.32 \mathrm{ppbv} \mathrm{yr}^{-1}$ (37 sites) with just 5 sites displaying a negative trend with a range of -0.08 to $-0.14 \mathrm{ppbv} \mathrm{yr}^{-1}$ (Fig. 12). Similarly, significant $(p<0.01)$ trends in annual 5th percentiles of $\mathrm{O}_{3}$ are also positive, with a range of 0.09 to $0.56 \mathrm{ppbv} \mathrm{yr}^{-1}$ (74 sites). Annual trends $(p<0.01)$ in 95 th percentiles of $\mathrm{O}_{3}$ tend to be negative with a range of -0.11 to $-0.46 \mathrm{ppbv} \mathrm{yr}^{-1}$ (20 sites). Comparing significant annual mean and 5th percentile trends in simulated and observed $\mathrm{O}_{3}$, the trends in simulated $\mathrm{O}_{3}$ lie within the broad range of observed trends. In the case of significant $(p<0.1)$ annual trends in 95th percentiles, contrary to the negative trends quantified from CHIMERE output, observed trends at almost half of the sites (71 sites) are positive. Inspection of the monthly mean $\mathrm{O}_{3}$ levels from the observed and simulated sites (Fig. 13), show that the CHIMERE model configuration slightly underestimates the mean $\mathrm{O}_{3}$ in winter and greatly over estimates the mean $\mathrm{O}_{3}$ levels from May to August, leading to differences between daily observed and simulated $\mathrm{O}_{3}$ annual trends in mean, 5th and 95th percentiles. 
Table 4. Summary of the average European annual trends (ppbv yr$r^{-1}$, with $2 \sigma$ error) from observations at all 158 sites in Fig. 1 and the CHIMERE simulation.

\begin{tabular}{c|c|ccc}
\hline Source & Period & $\begin{array}{c}\text { Mean } \\
\left(\mathrm{ppbv} \mathrm{yr}^{-1}\right)\end{array}$ & $\begin{array}{c}\text { 5th Percentile } \\
\left(\mathrm{ppbv} \mathrm{yr}^{-1}\right)\end{array}$ & $\begin{array}{c}\text { 95th Percentile } \\
\left(\mathrm{ppbv} \mathrm{yr}^{-1}\right)\end{array}$ \\
\hline $\begin{array}{c}\text { Observations - annual trend } \\
\text { CHIMERE - annual trend }\end{array}$ & $1996-2005$ & $0.16 \pm 0.02$ & $0.13 \pm 0.02$ & $0.16 \pm 0.03$ \\
$1996-2005$ & $0.05 \pm 0.01$ & $0.13 \pm 0.01$ & $-0.03 \pm 0.02$ \\
\hline
\end{tabular}
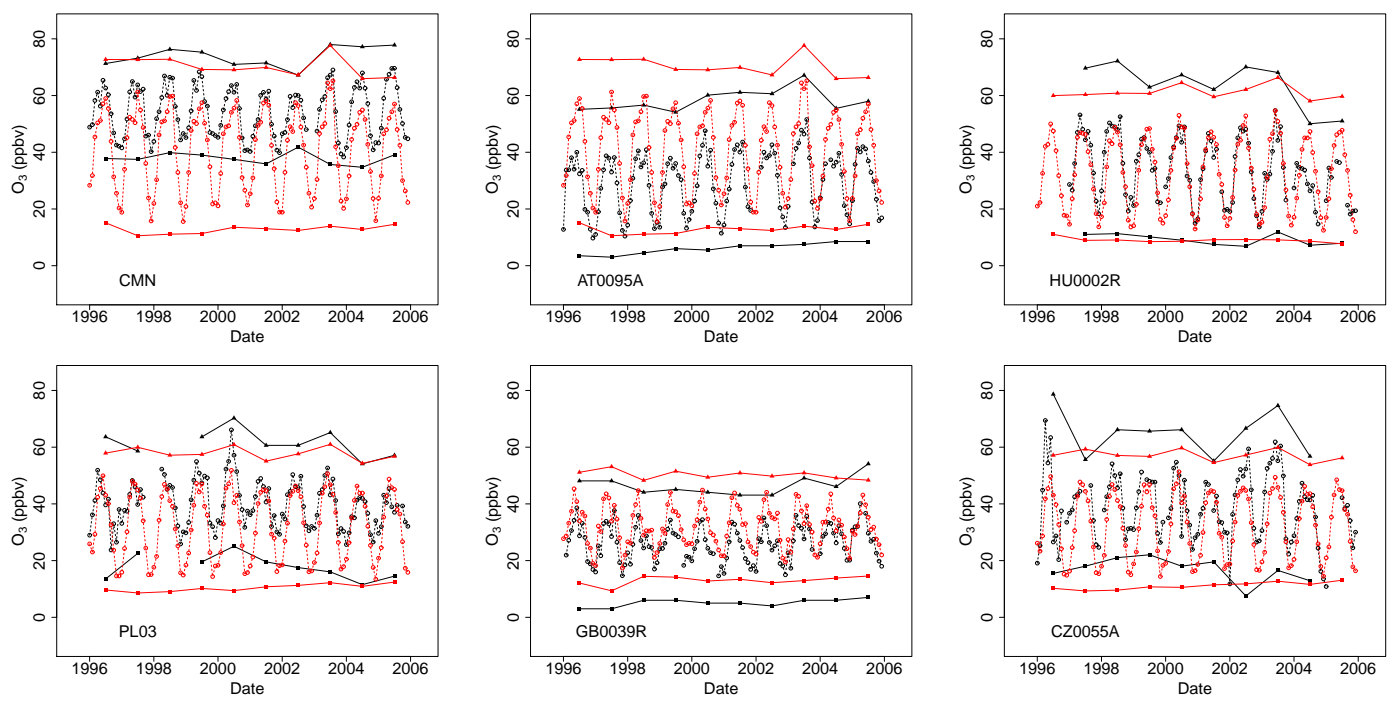

Fig. 11. Examples of loess trends of observed (black) and CHIMERE simulated (red) monthly mean $\mathrm{O}_{3}\left(\mathrm{ppbv} \mathrm{yr}^{-1}\right)$ (Full details of observed sites given in Fig. A1 of the Supplement, full CHIMERE simulated sites given in Appendix B Fig. B1 of the Supplement). Circles = monthly mean, squares $=$ annual 5 th percentile, triangle $=$ annual 95 th percentile .

Frequency distributions of the observed and CHIMERE modelled annual $\mathrm{O}_{3}$ trends in mean, 5th and 95th percentiles are given in Fig. 14 for (i) all trends and (ii) only those that are statistically significant $(p<0.1)$. It is clear that whilst the range of $\mathrm{O}_{3}$ annual trends is the same when looking at only statistically significant trends or all trends, the distribution of trends is different. In the observed trends the distribution is unimodal for $\mathrm{O}_{3}$ mean, 5th and 95th percentiles when accounting for all annual trends (with frequencies peaking at 0.1 to $0.2 \mathrm{ppbv} \mathrm{yr}^{-1}, 0.0$ to $0.1 \mathrm{ppbv} \mathrm{yr}^{-1}$ and 0.2 to $0.3 \mathrm{ppbv} \mathrm{yr}^{-1}$ respectively). When just statistically significant $(p<0.1)$ trends are taken into account, unimodal distribution of trends is seen for 5 th percentiles peaking at 0.2 to $0.3 \mathrm{ppbv} \mathrm{yr}^{-1}$, but bimodal distributions are seen for both

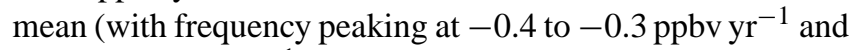
0.2 to $0.3 \mathrm{ppbv} \mathrm{yr}^{-1}$ ) and 95 th percentiles (with frequency

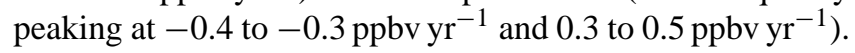

In comparison, ranges of CHIMERE annual $\mathrm{O}_{3}$ trends are similar for both mean and 5th percentiles whilst those for 95th percentiles are different. The CHIMERE annual $\mathrm{O}_{3}$ trends in mean, 5th and 95th percentiles exhibit a unimodal distribution when considering all trends (peaking at 0.0 to

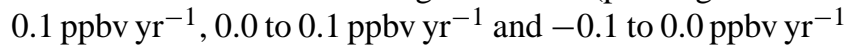

respectively). A unimodal distribution of the statistically significant trends of $\mathrm{O}_{3}$ mean (with frequency peaking at 0.1 to $0.2 \mathrm{ppbv} \mathrm{yr}^{-1}$ ), 5 th (with frequency peaking at 0.1 to $0.2 \mathrm{ppbv} \mathrm{yr}^{-1}$ ) and 95 th (with frequency peaking at -0.2 to $-0.1 \mathrm{ppbv} \mathrm{yr}^{-1}$ ) percentiles is also observed, in contrast to the bimodal distribution in observed $\mathrm{O}_{3}$ mean and 95th percentiles. The CHIMERE model distributions for annual trends in $\mathrm{O}_{3}$ mean, 5th and 95th percentiles tend to have a peak frequency at a lower value than the observed data.

The average European trends for annual mean, 5th and 95th $\mathrm{O}_{3}$ percentiles have been calculated, with $2 \sigma$ errors, for all sites observed and those extracted from the CHIMERE regional model (see Table 4). There is good agreement between the observed and CHIMERE Europeanaveraged 5th percentile trends $\left(0.13 \pm 0.02 \mathrm{ppbv} \mathrm{yr}^{-1}\right.$ and $0.13 \pm 0.01 \mathrm{ppbv} \mathrm{yr}^{-1}$ respectively). However, there is poorer agreement between the observed and the CHIMERE European-average trends in an mean $\left(0.16 \pm 0.02 \mathrm{ppbv} \mathrm{yr}^{-1}\right.$ and $0.05 \pm 0.01 \mathrm{ppbvyr}^{-1}$ respectively) and the 95 th percentiles $\left(0.16 \pm 0.03 \mathrm{ppbv} \mathrm{yr}^{-1}\right.$ and $-0.03 \pm 0.02 \mathrm{ppbv} \mathrm{yr}^{-1}$ respectively). 

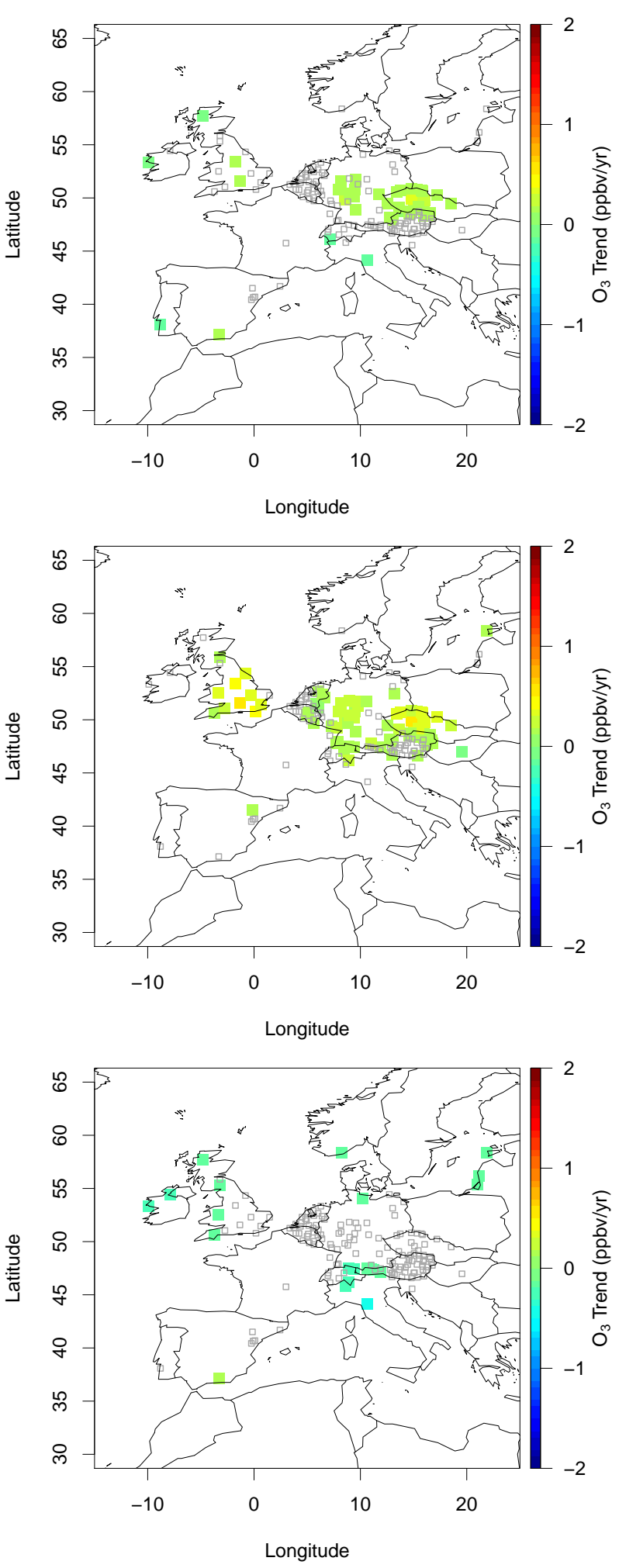

Fig. 12. Spatial distribution of significant $(p<0.1)$ annual CHIMERE modelled trends ( $\mathrm{ppbvyr}^{-1}$ ) in $\mathrm{O}_{3}$ mean (top), 5th (middle) and 95th percentiles (bottom) 1996-2005. Open squares $=$ sites with no statistically significant trends.

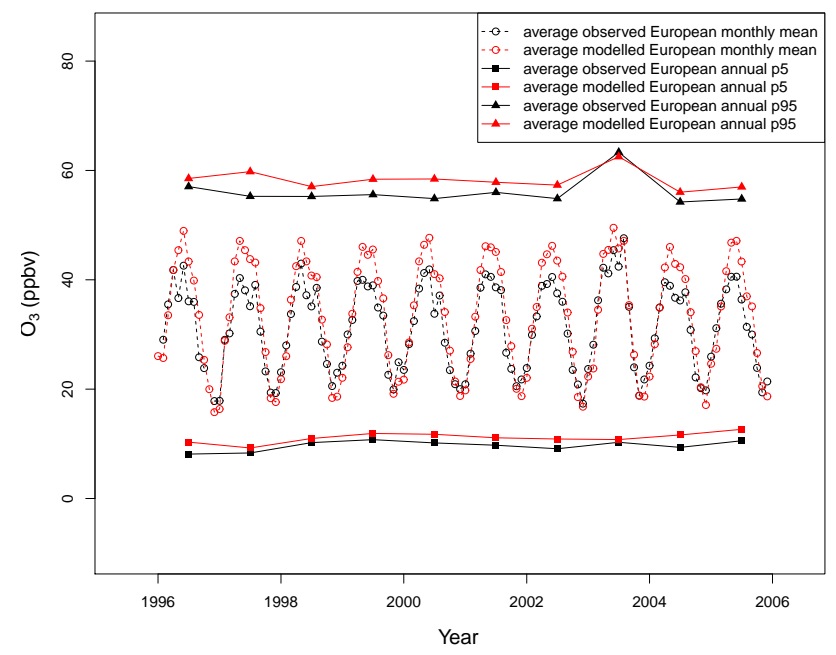

Fig. 13. A comparison of the European average $\mathrm{O}_{3}$ observed monthly mean and annual 5th and 95th percentiles and the CHIMERE model output for all 158 site locations.

\section{Summary and conclusions}

The establishment of temporal ozone trends is important for quantifying the impact of changing precursor emissions and also from the perspective of local and regional air quality control in terms of import/export of ozone and the amount that is locally or regionally controllable. Using ozone data from 158 European rural background observation sites over the time period 1996-2005, the annual and seasonal trends have been determined. A paucity of monitoring sites in France, Spain and the Mediterranean area in the harmonised dataset used (owing to not being available through the monitoring networks used) may lead to a bias towards the ozone trends within central/northern Europe. Ozone time-series at each station was manually characterised as having positive, negative, a combination of these increasing and decreasing concentrations, complex behaviour and static forms of temporal evolution.

Annual linear trends were calculated by de-seasonalising the ozone time series and using Mann-Kendall analysis of Sen-Theil slopes. The overall annual European-averaged trend was net positive, $0.16 \pm 0.02 \mathrm{ppbv} \mathrm{yr}^{-1}$ ( $2 \sigma$ error). When the European-averaged annual trends are decomposed into percentiles, both the 5th (background) and the 95th percentiles (peak) show positive trends of $0.13 \pm 0.02 \mathrm{ppbv} \mathrm{yr}^{-1}$ and $0.16 \pm 0.03 \mathrm{ppbv} \mathrm{yr}^{-1}$ respectively ( $2 \sigma$ error).

Stations in south-western and eastern Europe had negative trends in 5th and 95th percentiles and means, whereas most of the central and north-western stations had positive trends. Assessment of the sensitivity of the derived trends to the years included in the decadal average show that the net positive trend is heavily weighted by the $2003 \mathrm{NW} \mathrm{Eu}$ ropean "heatwave" year while the early part of the chosen 

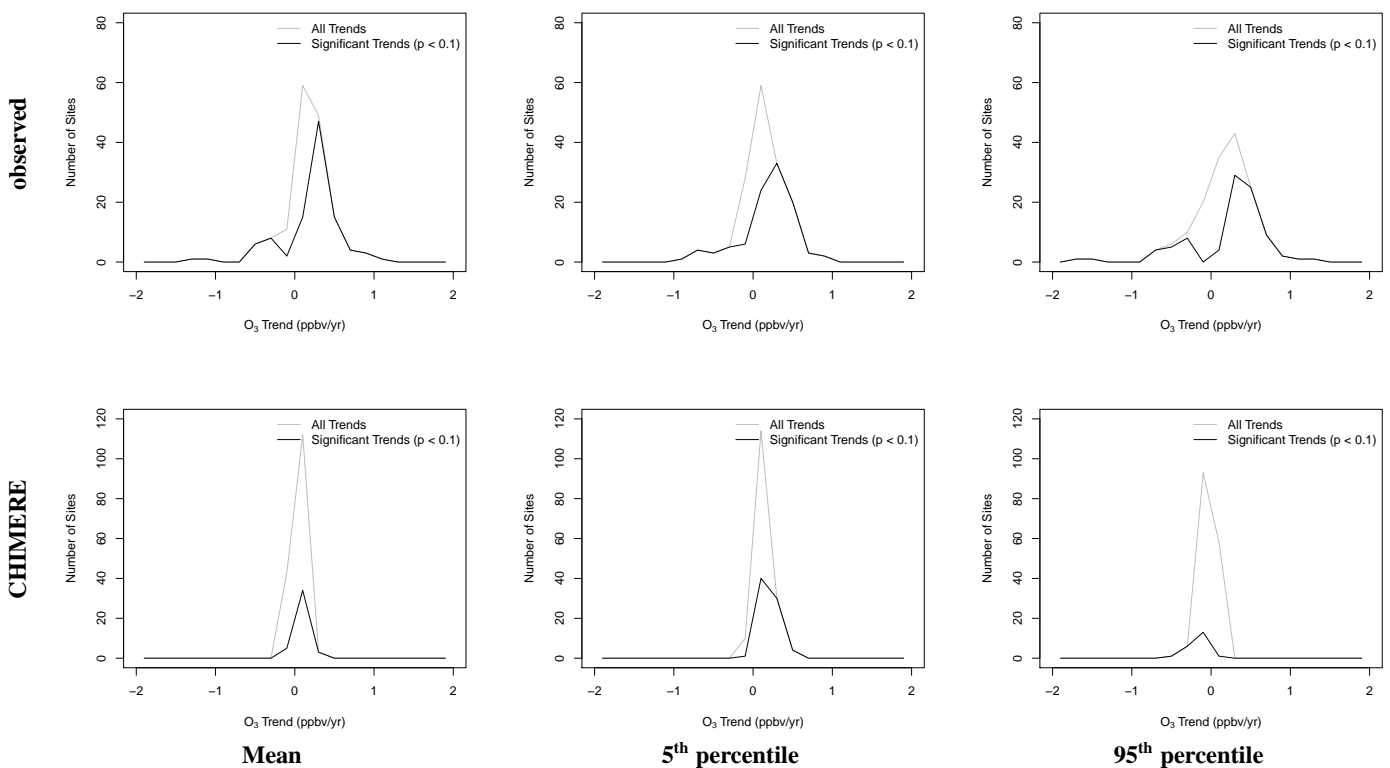

Fig. 14. A comparison of the frequency distribution of annual trends in observed (top) and CHIMERE (bottom) $\mathrm{O}_{3}$ mean, 5th and 95th percentiles.

decade is heavily influenced by 1997-1998 El Nino/biomass burning years. The dependency on the selection of the years highlights the role of variability driven by chemical and meteorological processes. The observed spatial variability of the trends could reflect the sphere of influence of the 2003 event (Vautard et al., 2005). It is clear that the identified year-by-year variations, caused by meteorological variability could be masking the impact of emission reductions on long-term ozone trends. In order to better assess the influence of emission changes on the observed ozone, alternative statistical approaches are required to remove the influence of the meteorological variability such as using general additive or generalised linear models (e.g. Chan, 2009; Chan and Vet, 2010).

European trends in $\mathrm{NO}_{\mathrm{x}}$ and VOC emissions from the EMEP inventory show near uniform decrease in ozone precursor emissions (apart from increases in $\mathrm{NO}_{\mathrm{x}}$ in southwestern Europe) across Europe which are not directly reflected in the observed ozone trends.

The average ozone seasonal cycle over Europe (from these 158 stations as shown in Fig. 8) displays a spring maximum for the 5th percentile and both a high spring maximum with a secondary summer maximum for the mean and 95th percentiles. There are positive seasonal ozone trends in spring, summer and autumn in 5th and 95th percentiles. The highest magnitude trend in 5th percentile and mean $\mathrm{O}_{3}$ are observed in winter $\left(0.26 \pm 0.07 \mathrm{ppbv} \mathrm{yr}^{-1}, 2 \sigma\right.$ error) and $0.26 \pm 0.07 \mathrm{ppbv} \mathrm{yr}^{-1}$ respectively. The highest trend out of all seasons was found in spring 95th percentiles $\left(0.31 \pm 0.09 \mathrm{ppbv} \mathrm{yr}^{-1}\right)$ and the summer 95 th percentile was also high $\left(0.24 \pm 0.10 \mathrm{ppbv} \mathrm{yr}^{-1}\right)$ and these periods of high photochemical activity would suggest an increase in ozone precursor build up and photolysis over the years. Mean, 5th and 95th percentile autumn ozone trends are negative, with the greatest negative magnitude observed in the 95th percentile $\left(-0.20 \pm 0.09 \mathrm{ppbv} \mathrm{yr}^{-1}\right)$.

Simulated ozone was extracted at the coordinates of the 158 measurement stations from the CHIMERE regional chemistry transport model. The CHIMERE model displays small positive annual trends in European-averaged mean ozone $\left(0.05 \pm 0.01 \mathrm{ppbv} \mathrm{yr}^{-1}\right)$ and 5 th percentiles $\left(0.13 \pm 0.01 \mathrm{ppbv} \mathrm{yr}^{-1}\right)$, with annual trends in 5 th percentiles closely matching that of European-average observed trends. It is noted that CHIMERE tends to overestimate the ozone levels in summer months relative to observed ozone, consequently CHIMERE European-averaged trends in 95th percentiles $\left(-0.03 \pm 0.02 \mathrm{ppbv} \mathrm{yr}^{-1}, 2 \sigma\right.$ error $)$ do not match those in observed ozone $\left(0.16 \pm 0.03 \mathrm{ppbv} \mathrm{yr}^{-1}\right)$. Expanded analysis of the CHIMERE model output and its validation against alternative (e.g. MOZAIC) or a limited number of longer datasets is required to investigate and understand the observed trends.

The ensemble approach of using many regional background sites does seem a robust way of exploring regional ozone trends. The ability to use distribution statistics on these ensembles as a way of challenging models needs to be explored further.

\section{Supplement related to this article is available online at: http://www.atmos-chem-phys.net/12/437/2012/ acp-12-437-2012-supplement.pdf.}


Acknowledgements. We would like to thank David Carslaw for his on-going support using and implementing the openair package in $\mathrm{R}$, Jean Louis Monge for his help in coding the meteorological preprocessor for CHIMERE and Øvind Hodnebrog for his comments on this manuscript. We acknowledge the support of the European Commission through the GEOmon (Global Earth Observation and Monitoring) Integrated Project under the 6th Framework Program (contract number FP6-2005-Global-4-036677).

Edited by: R. Cohen

\section{References}

2008/50/EC: Directive 2008/50/EC of the European Parliament and of the Council of 21 May 2008 On Ambient Air Quality And Cleaner Air For Europe, 2008.

Anfossi, D., Sandroni, S., and Viarengo, S.: Tropospheric Ozone in the 19th century - the Moncalieri series, J. Geophys. Res., 96, 17349-17352, 1991.

Brönnimann, S., Buchmann, B., and Wanner, H.: Trends in nearsurface ozone concentrations in Switzerland: the 1990s, Atmos. Environ., 36, 2841-2852, 2002.

Cape, J. N.: Surface ozone concentrations and ecosystem health: Past trends and a guide to future projections, Sci. Total Environ., 400, 257- 269, 2008.

Carslaw, D. and Ropkins, K.: Open-source tools for analysing air pollution data, Leeds, U.K., 2009.

Carslaw, D. C.: On the changing seasonal cycles and trends of ozone at Mace Head, Ireland, Atmos. Chem. Phys., 5, 34413450, doi:10.5194/acp-5-3441-2005, 2005.

Chan, E.: Regional ground-level ozone trends in the context of meteorological influences across Canada and the eastern United States from 1997 to 2006, J. Geophys. Res., 114, D05301, doi:10.1029/2008JD010090, 2009.

Chan, E. and Vet, R. J.: Baseline levels and trends of ground level ozone in Canada and the United States, Atmos. Chem. Phys., 10, 8629-8647, doi:10.5194/acp-10-8629-2010, 2010.

Chevalier, A., Gheusi, F., Delmas, R., Ordez, C., Sarrat, C., Zbinden, R., Thouret, V., Athier, G., and Cousin, J.-M.: Influence of altitude on ozone levels and variability in the lower troposphere: a ground-based study for western Europe over the period 2001-2004, Atmos. Chem. Phys., 7, 4311-4326, doi:10.5194/acp-7-4311-2007, 2007.

Cleveland, R. B., Cleveland, W. S., McRae, J. E., and Terpenning, I.: STL: A seasonal-trend decomposition procedure based on Loess, J. Official Statistics, 6, 3-73, 1990.

Cleveland, W. S.: Robust locally weighted regression and smoothing scatterplots, J. Am. Stat. Assoc., 74, 829-836, 1979.

Cooper, O., Derwent, D., Collins, B., Doherty, R., Stevenson, D., Stohl, A., and Hess, P.: Conceptual overview of hemispheric or intercontinental transport of ozone and particulate matter, chap. 1, 1-24, United Nations, New York and Geneva, 2010a.

Cooper, O. R., Parrish, D. D., Stohl, A., Trainer, M., Nédz'elec, P., Thouret, V., Cammas, J. P., Oltmans, S. J., Johnson, B. J., Tarasick, D., Leblanc, T., McDermid, I. S., Jaffe, D., Gao, R., Stith, J., Ryerson, T., Aikin, K., Campos, T., Weinheimer, A., and Avery, M. A.: Increasing springtime ozone mixing ratios in the free troposphere over western North America, Nature, 463, 344-348, 2010b.
Derwent, R. G., Jenkin, M., Saunders, S., Pilling, M., Simmonds, P., Passant, N., Dollard, G., Dumitrean, P., and Kent, A.: Photochemical ozone formation in north west Europe and its control, Atmos. Environ., 37, 1983-1991, 2003.

Derwent, R. G., Jenkin, M., Passant, N., and Pilling, M.: Photochemical ozone creation potentials (POCPs) for different emission sources of organic compounds under European conditions estimated with a Master Chemical Mechanism, Atmos. Environ., 41, 2570-2579, 2007a.

Derwent, R. G., Simmonds, P., Manning, A., and Spain, T.: Trends over a 20-year period from 1987 to 2007 in surface ozone at the atmospheric research station, Mace Head, Ireland, Atmos. Environ., 41, 9091-9098, 2007b.

Derwent, R. G., Witham, C. S., Utembe, S. R., Jenkin, M. E., and Passant, N. R.: Ozone in Central England: the impact of 20 years of precursor emission controls in Europe, Environ. Sci. Pol., 13, 195-204, 2010.

EEA: Air Pollution in Europe 1990-2004, EEA Report No2/2007, European Environment Agency, Copenhagen, 2007.

Finzi, G. and Lechi, G.: LANDSAT images of urban air pollution in stable meteorological conditions, Il Nuovo Cimento C, 14, 433443, 1991.

Fiore, A. M., Jacob, D. J., Bey, I., Yantosca, R. M., Field, B. D., Fusco, A. C., and Wilkinson, J. G.: Background ozone over the United States in summer: Origin, trend, and contribution to pollution episodes, J. Geophys. Res., 107, 4275, doi:10.1029/2001JD000982, 2002.

Fowler, D., Cape, N., Coyle, M., Flechard, C., Kuylenstierna, J., Hicks, K., Derwent, D., Johnson, C., and Stevenson, D.: The global exposure of forests to air pollutants, Water Air Soil Pollut., 116, 5-32, 1999.

Fowler, D., Pilegaard, K., Sutton, M., Ambus, P., Raivonen, M., Duyzer, J., Simpson, D., Fagerli, H., Fuzzi, S., Schjoerring, J., Granier, C., Neftel, A., Isaksen, I., Laj, P., Maione, M., Monks, P., Burkhardt, J., Daemmgen, U., Neirynck, J., Personne, E., Wichink-Kruit, R., Butterbach-Bahl, K., Flechard, C., Tuovinen, J., Coyle, M., Gerosa, G., Loubet, B., Altimir, N., Gruenhage, L., Ammann, C., Cieslik, S., Paoletti, E., Mikkelsen, T., Ro-Poulsen, H., Cellier, P., Cape, J., Horváth, L., Loreto, F., Niinemets, U., Palmer, P., Rinne, J., Misztal, P., Nemitz, E., Nilsson, D., Pryor, S., Gallagher, M., Vesala, T., Skiba, U., Brüggemann, N., Zechmeister-Boltenstern, S., Williams, J., O’ Dowd, C., Facchini, M., de Leeuw, G., Flossman, A., Chaumerliac, N., and Erisman, J.: Atmospheric composition change: ecosystems-atmosphere interactions, Atmos. Environ., 43, 5193-5267, 2009.

Gerasopoulos, E., Kouvarakis, G., Vrekoussis, M., Kanakidou, M., and Mihalopoulos, N.: Ozone variability in the marine boundary layer of the eastern Mediterranean based on 7-year observations, J. Geophysical Research, 110, D15 309, 2005.

Gigzdiene, R. and Girgzdys, A.: Ozone trend and seasonal cycle at the Preila station, in: Tropospheric Ozone Research, Final Report of Subproject TOR-2, EUROTRAC-2, ISS, Munich, 79-83, 2003.

Guicherit, R. and Roemer, M.: Tropospheric ozone trends, Chemosphere - Global Change Sci., 2, 167-183, 2000.

Haszpra, L., Ferenczi, Z., Lagzi, I., and Turányi, T.: Formation of tropospheric ozone in Hungary, in: Tropospheric Ozone Research, Final Report of Subproject TOR-2, EUROTRAC-2, ISS, Munich, 87-89, 2003. 
Henne, S., Brunner, D., Folini, D., Solberg, S., Klausen, J., and Buchmann, B.: Assessment of parameters describing representativeness of air quality in-situ measurement sites, Atmos. Chem. Phys., 10, 3561-3581, doi:10.5194/acp-10-3561-2010, 2010.

Hess, A., Iyer, H., and Malm, W.: Linear trend analysis: a comparison of methods, Atmos. Environ., 35, 5211-5222, doi:10.1016/S1352-2310(01)00342-9, 2001.

Hirsch, R. M., Slack, J., and Smith, R. A.: Techniques of trend analysis for monthly water-quality data, Water Resour. Res., 18, 107-121, 1982.

IPCC, ed.: Climate Change 2007: The physical science basis. Contribution of working group I to the fourth assessment report of the Intergovernmental Panel on Climate Change. Chapter 1, Historical overview of climate change, Cambridge University Press, Cambridge, 2007.

Jaffe, D. and Ray, J.: Increase in surface ozone at rural sites in the western US, Atmos. Environ., 41, 5452-5463, 2007.

Jaffe, D., Bertschi, I., Jaeglé, L., Novelli, P., Reid, J. S., Tanimoto, H., Vingarzan, R., and Westphal, D. L.: Long-range transport of Siberian biomass burning emissions and impact on surface ozone in western North America, Geophys. Res. Letters, 311, L16106, doi:10.1029/2004GL020093, 2004.

Jenkin, M. E.: Trends in ozone concentration distributions in the UK since 1990: Local, regional and global influences, Atmos. Environ., 42, 5434-5445, 2008.

Jonson, J. E., Simpson, D., Fagerli, H., and Solberg, S.: Can we explain the trends in European ozone levels?, Atmos. Chem. Phys., 6, 51-66, doi:10.5194/acp-6-51-2006, 2006.

Keating, T. and Zuber, A.: Hemispheric transport of air pollution 2007, Air Pollution Studies No. 16, UNECE, Geneva, 2007.

Konovalov, I. B., Beekmann, M., Burrows, J. P., and Richter, A.: Satellite measurement based estimates of decadal changes in European nitrogen oxides emissions, Atmos. Chem. Phys., 8, 2623 2641, doi:10.5194/acp-8-2623-2008, 2008.

Koumoutsaris, S., Bey, I., Generoso, S., and Thouret, V.: Influence of El Niño southern oscillation on the interannual variability of tropospheric ozone in the northern midlatitudes, J. Geophys. Res., 113, D19301, doi:10.1029/2007JD009753, 2008.

Law, K., Parrish, D., Arnold, S., Chan, E., Chen, G., Cooper, O., Derwent, D., Edwards, D., Jaffe, D., Koch, D., Laj, P., Martin, R., Methven, J., Monks, P. S., Penkett, S. A., Prospero, J., Quinn, P., Remer, L., Staehelin, J., Scheffe, R., Takami, A., Tanimoto, H., Thouret, V., Turquety, S., Zdanowicz, C., and Ziemke, J.: Observational evidence and capabilities related to intercontinental transport of ozone and particualte matter, United Nations, New York and Geneva, chap. 2, 25-75, 2010.

Lee, J. D., Lewis, A. C., Monks, P. S., Jacob, M., Hamilton, J. F., Hopkins, J. R., Watson, N. M., Saxton, J. E., Ennis, C., Carpenter, L. J., Carslaw, N., Fleming, Z., Bandy, B. J., Oram, D. E., Penkett, S. A., Slemr, J., Norton, E., Rickard, A. R., Whalley, L. K., Heard, D. E., Bloss, W. J., Gravestock, T., Smith, S. C., Stanton, J., Pilling, M. J., and Jenkin, M. E.: Ozone photochemistry and elevated isoprene during the UK heatwave of august 2003, Atmos. Environ., 40, 7598-7613, 2006.

Lindskog, A., Beekmann, M., Monks, P. S., Roemer, M., Schuepbach, E., and Solberg, S.: Tropospheric Ozone Research - TOR2, in: Tropospheric Ozone Research, Final Report of Subproject TOR-2, EUROTRAC-2, ISS, Munich, 1-28, 2003.

Monks, P. S.: A review of the observations and origins of the spring ozone maximum, Atmos. Environ., 34, 3545-3561, 2000.

Monks, P. S.: Gas-phase radical chemistry in the troposphere, Chem. Soc. Rev., 34, 376-395, 2005.

Monks, P. S., Granier, C., Fuzzi, S., Stohl, A., Williams, M., Akimoto, H., Amann, M., Baklanov, A., Baltensperger, U., Bey, I., Blake, N., Blake, R., Carslaw, K., Cooper, O., Dentener, F., Fowler, D., Fragkou, E., Frost, G., Generoso, S., Ginoux, P., Grewe, V., Guenther, A., Hansson, H., Henne, S., Hjorth, J., Hofzumahaus, A., Huntrieser, H., Isaksen, I., Jenkin, M., Kaiser, J., Kanakidou, M., Klimont, Z., Kulmala, M., Laj, P., Lawrence, M., Lee, J., Liousse, C., Maione, M., McFiggans, G., Metzger, A., Mieville, A., Moussiopoulos, N., Orlando, J., O’Dowd, C., Palmer, P., Parrish, D., Petzold, A., Platt, U., Pöschl, U., Prévôt, A., Reeves, C., Reimann, S., Rudich, Y., Sellegri, K., Steinbrecher, R., Simpson, D., ten Brink, H., Theloke, J., van der Werf, G., Vautard, R., Vestreng, V., Vlachokostas, C., and von Glasow, R.: Atmospheric composition change - global and regional air quality, Atmos. Environ., 43, 5268-5350, 2009.

National Research Council: Global sources of local pollution: An assessment of long-range transport of key air pollutants to and from the United States, The National Academies Press, Washington, DC, USA, 248 pp., 2009.

Oltmans, S. J., Lefohn, A., Harris, J., Galbally, I., Scheel, H., Bodeker, G., Brunke, E., Claude, H., Tarasick, D., Johnson, B., Simmonds, P., Shadwick, D., Anlauf, K., Hayden, K., Schmidlin, F., Fujimoto, T., Akagi, K., Meyer, C., Nichol, S., Davies, J., Redondas, A., and Cuevas, E.: Long-term changes in tropospheric ozone, Atmos. Environ., 40, 3156-3173, 2006.

Oltmans, S. J., Galbally, I. E., Brunke, E.-G., Meyer, C. P., Lathrop, J. A., Johnson, B. J., Shadwick, D. S., Cuevas, E., Schmidlin, F. J., Tarasick, D. W., Claude, H., Kerr, J. B., Uchino, O., and Mohnen, V.: Trends of ozone in the troposphere, Geophys. Res. Lett., 25, 139-142, doi:10.1029/97GL03505, 1998.

Oltmans, S. J., Lefohn, A. S., Harris, J. M., and Shadwick, D. S.: Background ozone levels of air entering the west coast of the US and assessment of longer-term changes, Atmos. Environ., 42, 6020-6038, 2008

Ordóñez, C., Mathis, H., Furger, M., Henne, S., Hglin, C., Staehelin, J., and Prévôt, A. S. H.: Changes of daily surface ozone maxima in Switzerland in all seasons from 1992 to 2002 and discussion of summer 2003, Atmos. Chem. Phys., 5, 1187-1203, doi:10.5194/acp-5-1187-2005, 2005.

Parrish, D. D.: Critical evaluation of US on-road vehicle emission inventories, Atmos. Environ., 40, 2288-2300, 2006.

Parrish, D. D., Millet, D., and Goldstein, A.: Increasing ozone in marine boundary layer inflow at the west coasts of North America and Europe, Atmos. Chem. Phys., 9, 1303-1323, doi:10.5194/acp-9-1303-2009, 2009.

Parrish, D. D., Trainer, M., Hereid, D., Williams, E. J., Olszyna, K. J., Harley, R. A., Meagher, J. F., and Fehsenfeld, F. C.: Decadal change in carbon monoxide to nitrogen oxide ratio in U.S. vehicular emissions, J. Geophys. Res., 107, 4140, doi:10.1029/2001JD000720, 2002.

Pavelin, E., Johnson, C., Rughooputh, S., and Toumi, R.: Evaluation of pre-industrial surface ozone measurements made using Schönbein's method, Atmos. Environ., 33, 919-929, 1999.

R Development Core Team: An introduction to R, R Foundation for Statistical Computing, Vienna, Austria, 2009.

Sandroni, S., Anfossi, D., and Viarengo, S.: Surface ozone levels at 
the end of the 19th century in South America, J. Geophys. Res.Atmos., 97, 2535-2539, 1992.

Schmidt, H., Derognat, C., Vautard, R., and Beekmann, M.: A comparison of simulated and observed ozone mixing ratios for the summer of 1998 in Western Europe, Atmos. Environ., 35, 62776297, 2001.

Sicard, P., Coddeville, P., and Galloo, J.: Near-surface ozone levels and trends at rural stations in France over the 1995-2003 period, Environ. Monit. Assess., 156, 141-157, 2009.

Sicard, P., Mangin, A., Hebel, P., and Malla, P.: Detection and estimation trends linked to air quality and mortality on French Riviera over the 1990-2005 period, Sci. Total Environ., 408, 19431950, 2010.

Simmonds, P. G., Derwent, R. G., Manning, A. L., and Spain, G.: Significant growth in surface ozone at Mace Head, Ireland, 1987-2003, Atmos. Environ., 38, 4769-4778, 2004.

Solberg, S., Hov, O., Søvde, A., Isaksen, I. S. A., Coddeville, P., Backer, H. D., Forster, C., Orsolini, Y., and Uhse, K.: European surface ozone in the extreme summer 2003, Geophys. Res. Lett., 113, D07307, doi:10.1029/2007JD009098, 2008.

Solberg, S., Jonson, J. E., Horalek, J., Larssen, S., and de Leeuw, F.: Assessment of ground-level ozone in EEA member countries, with a focus on long-term trends, EEA Report No7/2009, European Environment Agency, Copenhagen, 2009.

Staehelin, J., Thudium, J., Buehler, R., Volz-Thomas, A., and Graber, W.: Trends in surface ozone concentrations at Arosa (Switzerland), Atmos. Environ., 28, 75-87, 1994.

Szopa, S., Hauglustaine, D., Vautard, R., and Menut, L.: Future global tropospheric ozone changes and impact on European air quality, Geophys. Res. Lett., 33, L14805, doi:10.1029/2006GL025860, 2006.

Tanimoto, H., Ohara, T., and Uno, I.: Asian anthropogenic emissions and decadal trends in springtime tropospheric ozone over Japan: 1998-2007, Geophysical Research Letters, 36, L23802, doi:10.1029/2009GL041382, 2009.

The Royal Society: Ground-level ozone in the 21st century: future trends, impacts and policy implications, London, UK, 132 pp., 2008.

Thompson, M. L., Reynolds, J., Cox, L. H., Guttorp, P., and Sampson, P. D.: A review of statistical methods for the meteorological adjustment of tropospheric ozone, Atmos. Environ., 35, 617630, doi:10.1016/S1352-2310(00)00261-2, 2001.

Tripathi, O. P., Jennings, S. G., O’Dowd, C. D., Coleman, L., Leinert, S., O'Leary, B., Moran, E., O’Doherty, S. J., and Spain, T. G.: Statistical analysis of eight surface ozone measurement series for various sites in Ireland, J. Geophys. Res., 115, D19302, doi:10.1029/2010JD014040, 2010.

Vautard, R., Honor, C., Beekmann, M., and Rouil, L.: Simulation of ozone during the August 2003 heat wave and emission control scenarios, Atmos. Environ., 39, 2957-2967, 2005.
Vautard, R., Szopa, S., Beekmann, M., Menut, L., Hauglustaine, D. A., Rouil, L., and Roemer, M.: Are decadal anthropogenic emission reductions in Europe consistent with surface ozone observations?, Geophys. Res. Lett., 33, L13810, doi:10.1029/2006GL026080, 2006.

Vestreng, V., Rigler, E., Adams, M., Kindbom, K., Pacyna, J., Denier van der Gon, H., Reis, S., and Travnikov, O.: Inventory review 2006, Emission data reported to LRTAP and NEC Directive, Stage 1, 2 and 3 review and Evaluation of inventories of HM and POPs, Tech. Rep. 1/2006, EMEP/MSC-W Technical Report, 2006.

Vestreng, V., Ntziachristos, L., Semb, A., Reis, S., Isaksen, I. S. A., and Tarrasn, L.: Evolution of $\mathrm{NO}_{\mathrm{x}}$ emissions in Europe with focus on road transport control measures, Atmos. Chem. Phys., 9, 1503-1520, doi:10.5194/acp-9-1503-2009, 2009.

Vingarzan, V.: A review of surface ozone background levels and trends, Atmos. Environ., 38, 3431-3442, 2004.

Volz, A. and Kley, D.: Evaluation of the Montsouris series of ozone measurements made in the nineteenth century, Nature, 332, 240 242, 1988.

von Schneidemesser, E., Monks, P. S., and Plass-Duelmer, C.: Global comparison of VOC and CO observations in urban areas, Atmos. Environ., 44, 5053-5064, 2010.

Voulgarakis, A., Savage, N. H., Wild, O., Braesicke, P., Young, P. J., Carver, G. D., and Pyle, J. A.: Interannual variability of tropospheric composition: the influence of changes in emissions, meteorology and clouds, Atmos. Chem. Phys., 10, 2491-2506, doi:10.5194/acp-10-2491-2010, 2010.

Weatherhead, E. C., Reinsel, G. C., Tiao, G. C., Meng, X., Choi, D., Cheang, W., Keller, T., DeLuisi, J., Wuebbles, D. J., Kerr, J. B., Miller, A. J., Oltmans, S. J., and Frederick, J. E.: Factors affecting the detection of trends: Statistical considerations and applications to environmental data, J. Geophys. Res., 103, 17149-17161, 1998.

Weatherhead, E. C., Stevermer, A. J., and Schwartz, B. E.: Detecting environmental changes and trends, Physics and Chemistry of the Earth, 27, 399-403, 2002.

WHO: Health aspects of air pollution with particulate matter, ozone and nitrogen dioxide, World Health Organisation, Bonn, 2003.

Xu, X., Lin, W., Wang, T., Yan, P., Tang, J., Meng, Z., and Wang, Y.: Long-term trend of surface ozone at a regional background station in eastern China 1991-2006: enhanced variability, Atmos. Chem. Phys., 8, 2595-2607, doi:10.5194/acp-8-2595-2008, 2008.

Zvyagintsev, A. and Tarasova, O.: Trends of surface ozone concentrations in germany and their connections with changes in meteorological variables, Russ. Meteorol. Hydrol., 36, 258-264, 2011. 